\title{
BIBLIOGRAFIJA DRAGE ROKSANDIĆA
}

\author{
A. Knjige str. 1095-1097 \\ B. Rasprave, članci, poglavlja u knjizi ili časopisu str. 1097-1114 \\ C. Urednički, redaktorski i recenzentski radovi str. 1114-1136 \\ D. Prikazi, ocjene, recenzije str. 1136-1145 \\ E. Izdanja izvora str. 1145-1152 \\ F. Leksikografske natuknice str. 1152-1154 \\ G. Nekrolozi str. 1154 \\ H. Prijevodi str. 1154
}

\section{A. KNJIGE}

\section{8.}

Vojna Hrvatska: Vojna Hrvatska - La Croatie militaire. Krajiško društvo u Francuskom Carstvu (1809-1813), sv. 1-2, Biblioteka Povijesna istraživanja, Zagreb 1988., 360 + 282 str. Vidjeti izvorni rukopis disertacije: Hrvatska Vojna krajina pod francuskom vlašću: Knjiga I. - II., Zagreb 1988., 1-474 i 475-965. (Rukopis je dostupan u Arhivu Filozofskog fakulteta Sveučilišta u Zagrebu.)

Vidjeti, također: „Krajiška refeudalizacija i počeci modernizacije”, u: „Počeci moderne Hrvatske“, Naše teme, 33/1989, br. 7-8, 1912-1954; Miroslav BERTOŠA, "Jedan metodološki obrazac socijalne historije: Studija-pilot Drage Roksandića o Vojnoj krajini“ , Nastava istorije/Nastava povijesti/ Nastava po istorija/Pouk zgodovine, 3/1989., 164-168; Miroslav BERTOŠA, "Multidisciplinaran pristup", Školske novine, br. 1867, 30. 5. 1989., 13; Mario STRECHA, „Uzoran primjer 'nove historije'“, Republika, 9-10/1989., 269-275; Žarko ŠPANIČEK, „Prikaz”, Narodna umjetnost, 27/1990., 254-255; Husnija Kamberović, „'Vojna Hrvatska. La Croatie Militaire“, Prilozi Instituta za historiju, 25-26/1990., 356.

1991.

Srbi u Hrvatskoj od 15. stoljeća do naših dana, Biblioteka Vjesnik vremena - posebno izdanje, Vjesnik, Zagreb 1991., u: Prosvjeta, 11/2004., br. 63, 31-32.

Vidjeti: „Srbi u Hrvatskoj od 15. stoljeća do naših dana“, Vjesnik, 7. 9. - 13. 10. 1990.

Vidjeti, također: „Povijest srpskog naroda u Hrvatskoj. Priručnik za nastavnike: Projekt“ ,Prosvjeta. Novine za kulturu, 11/2004., br. 63, 29-40; br. 64, 29-40; br. 65, 29-40; 12/2005., br. 67, 29-40; br. 68, 29-40; br. 69, 29-40; br. 70, 33-36. Objavljeni prilozi autora za „Povijest srpskog naroda u Hrvatskoj. Priručnik za nastavnike": Drago Roksandić; Fedor MOAČAnIN; Miroslav BerToŠA, Nenad Moačanin; Branka Prpa; Nikša Stančić; Mirjana Gross; Mile BJelajac; Ljubo Boban; Mira Kolar-Dimitrijević; Janko Pleterski; Željko Pajić; Stanko Korać.

Srpska i hrvatska povijest i 'nova historija', Biblioteka Memoria, Stvarnost, Zagreb 1991., 316 str.

Vidjeti: Srpska i hrvatska povijest i 'nova historija', Tokyo 1999., 286 str. Japanski.

Japanski prijevod knjige koja je pod istim naslovom prvi put objavljena u Zagrebu 1991. Prevoditelj: prof. dr. sc. Isao Koshimura. („Roksandić na japanskom“, Prosvjeta, 7/2000., br. 37/38, 25) 
1996.

Protiv rata. Prilozi povijesti iluzija, Biblioteka Politea, SKD Prosvjeta, Zagreb 1996., 164 str.

\section{3.}

Triplex Confinium ili o granicama i regijama hrvatske povijesti 1500-1800, Biblioteka Homines, tempora, loci, Barbat, Zagreb 2003., 259 str.

Vidjeti: Nataša KNEZović, u: Epulon, 2/2004., br. 2, 94-96; Karolina BuzIAK, u: Ekonomska i ekohistorija: časopis za gospodarsku povijest i povijest okoliša, 2/2006., br. 1, 159-161; Marin Percan, u: Epulon, 5/2004., br. 5, 149-152.

\section{4.}

Etnos, konfesija, tolerancija, Biblioteka Historijska istraživanja, SKD Prosvjeta, Zagreb 2004., 480 str.

Vidjeti: Sanja Lazanin, u: Migracijske i etničke teme, 22/2006., 447-449.

\section{6.}

Svetozar Borojević od Bojne (1856 - 1920). Lav ili Lisica sa Soče, Vijeće srpske nacionalne manjine grada Zagreba, Zagreb 2006., 64 str.

\section{1.}

U NIN-u i Danasu, SKD Prosvjeta, Zagreb 2011., 368 str.

Vidjeti: Egidio IVETIć, „Protiv povjesničarske palanke (Drago Roksandić u NIN-u i Danasu (1983.1990.)“, Historijski zbornik, 66/2013., br. 1, 217-229; Stipe KuJAıć, "Drago Roksandić, U NIN-u i Danasu, Zagreb: SKD Prosvjeta, 2011, 368 str.“, Migracijske i etničke teme, 28/2012., br. 2, 215-220; Tomislav BranĐolica, „Drago Roksandić, U NIN-u i Danasu, Zagreb: SKD „Prosvjeta“, 2011, 368 str.“, Pro tempore, 10-11/2016., 606-607.

\section{6.}

Drago Roksandić; Vlatka FILIPČić MaliGEC, Kultura hrvatskog antifašizma. Prvi kongres kulturnih radnika Hrvatske (Topusko, 25. - 27. lipnja 1944.). Između „mjesta pamćenja“ i kritičke refleksije, Zagrebačka naklada - Filozofski fakultet Sveučilišta u Zagrebu, Centar za komparativnohistorijske i interkulturne studije, Zagreb 2016., 304 str.

Vidjeti: Matko GıobaČNIK, „Partizanska prijestolnica kulture“, Radovi Zavoda za hrvatsku povijest Filozofskog fakulteta Sveučilišta u Zagrebu, 50/2018., br. 2, 352-354.

\section{7.}

Iluzija slobode. Ogledi o Vladanu Desnici, Biblioteka Universitas, Politička kultura, nakladno-istraživački zavod, Zagreb 2017., 252 str.

Vidjeti: Miroslav ARTIĆ, „Sloboda između banalnosti i utopije“, https://arteist.hr/drago-roksandic-iluzije-slobode/ 
2018.

Čovjek i prostor, čovjek u okolišu. Ekohistorijski ogledi, Bibliotheca Historia Croatica, Meridijani - Društvo za hrvatsku povjesnicu - Filozofski fakultet Sveučilišta u Zagrebu, Centar za komparativnohistorijske i interkulturne studije, Zagreb - Samobor 2018., 432 str. Vidjeti: Hrvoje Petrić, „Važan doprinos poznavanju problematike prostora i okoliša u povijesti", Radovi Zavoda za hrvatsku povijest Filozofskog fakulteta Sveučilišta u Zagrebu, 50/2018., br. 2, 361-364.

Historiografija u tranziciji, Biblioteka Posebna izdanja, SKD Prosvjeta, Zagreb 2018., 564 str. Vidjeti: Matko GlobaČNIK, „Uz knjigu 'Historiografija u tranziciji' Drage Roksandića“, Tragovi, 2/2019., br. 1, 199-211; Aleksandar JAKIR, „Drago Roksandić: Historiografija u traziciji“, Tragovi, 2/2019., br. 1, 215-219; Olga ManOJLOvić-PINTAR, „Historiografija u tranziciji”, Tragovi, 2/2019., br. 1, 220-224.

\section{B. RASPRAVE, ČLANCI, POGLAVLA U KNJIZI ILI ČASOPISU}

1970.

„Savez omladine u procesima odgoja i obrazovanja / Savez omladine u školi“, u: Samoupravna socijalistička škola (ur. Nenad Brkić; Radovan Stipanović; Rade Kalanj), Centar za društvene djelatnosti omladine Republičke konferencije Saveza omladine Hrvatske, Zagreb 1970., 35-44.

1971.

„Srbi u hrvatskoj domovini“, Omladinski tjednik, 5/1971., br. 127, 14. 4. 1970., 2.

Vidjeti, također: „Kriza povjerenja ili Srbi u hrvatskoj domovini“, Hrvatski tjednik, 1/1971., br. 2, [24], tj. isti tekst s komentarom priređivača „V. P.", vjerojatno Vlatka Pavletića.

U proljeće 1987. godine ovaj je tekst iznenada "otkrio“ prof. dr. Vasilije Krestić, na čijem sam predmetu "Istorija naroda Jugoslavije u Novom veku“ na Odeljenju za istoriju Filozofskog fakulteta Univerziteta u Beogradu bio asistent od 17. travnja 1978. godine, dakle u vrijeme kada se Srbija oficijelno počela „prebrojavati“ na „Obiliće“ $\mathrm{i}$ „Brankoviće“. Vidjeti:

„Univerzitet i moralnopolitička podobnost (o montiranom političkom procesu na Filozofskom fakultetu beogradskog Univerziteta", Naše teme, 34/1990., br. 3-4, 516-600.

1974.

„Saradnja na principima nesvrstanosti“, u: Deveti kongres Saveza socijalističke omladine Jugoslavije (Dokumenti) (ur. Mladen Arnautović), NIP Mladost, Beograd 1974., 80-88. „Komisija za međunarodnu aktivnost i saradnju. Uvodno izlaganje Drage Roksandića“

\section{5.}

Hrvatska u doba Marije Terezije (1740-1780). Diplomski rad, Filozofski fakultet Univerziteta u Beogradu, Beograd 1975., 74 str. /strojopis/

Mentor: prof. dr. Vasilije KRESTIĆ 
1979.

„Razvoj međunarodnih odnosa socijalističke Jugoslavije 1941-1954", u: Međunarodni odnosi i vanjska politika socijalističke Jugoslavije (prir. Inoslav Bešker), Naklada CDD, Zagreb 1979., 32-51.

\section{2.}

„Bune u Senju i Primorskoj krajini (1719-1722)“, Radovi Instituta za hrvatsku povijest Sveučilišta u Zagrebu, 15/1982., 33-106.

Bune u Senju i Primorskoj krajini (1719 - 1722). Magistarski rad prijavljen je i obranjen na Filozofskom fakultetu Univerziteta u Beogradu 1980. godine. Integralan tekst magistarskog rada ima 193 strojopisne kartice s prilozima (161 + 32 str.) i rekonstruiranu kartu Primorske krajine u to doba. Mentor: prof. dr. Vasilije KRESTIĆ

„Vojna krajina i 'nova historija'“, Naše teme, 26/1982., br. 11, 1917-1926.

„Vojna krajina i ‘nova historija'. Povodom Zbornika Vojna krajina. Povijesni pregled - historiografija

- rasprave (Zagreb 1984)“, Zbornik Centra za društvena istraživanja Slavonije i Baranje, 22/1985., br. 1, 343-353.

\section{3.}

„Prilog", Gledišta, 24/1983., 1-2, 117-120.

Tema broja: „Etnos, narod, nacija (Naučni skup u MC CK SKS)“ (3-185)

"Mogućnosti rasprave o omladini i društvenim krizama", u: Omladina i društvene krize (ur. Dobrica Vulović), Centar za marksizam univerziteta u Beogradu, Beograd 1983., 68-73.

"Jugoslovensko i nacionalno u udžbenicima istorije" , Marksistička misao, 2/1983., 163-210.

„Uvodna napomena“ (163-165); Ivan OBradović, „Kvantitativna analiza pojavljivanja ličnih imena" (166-177); Đorđe STANKOvić, "Prevlast tradicionalističke političke istorije“ (177-183); Nikša STANČı́́, „Htijenja školske reforme i njihovo ostvarenje u udžbenicima povijesti za srednje škole - zajednička jezgra“ (184-188); Drago RoksAnDIĆ, "Historijska svijest i nastava povijesti u srednjim školama“ (188-191)

"Globalna istorija i istorijska svest", Marksistička misao, 4/1983., 45-58.

„Osnovna tema: Suvremenost i istorijska svest“ (Andrej Mitrović; Todor Kulıć; Đorđe Đ. Stanković; Drago Roksandić; Branko Petranović) (3-82)

\section{4.}

„Drago Roksandić", u: Aporije Hrvatskog biografskog leksikona. Rasprava o Hrvatskom biografskom leksikonu, sv. 1 / A-Bi (ur. Sanja Vrhovec), Edicija Centra za idejno-teorijski rad GK SKH Zagreb, Zagreb 1984., 59-67.

„Rasprave o ukidanju krajiškog uređenja u Vojnoj Hrvatskoj (1809-1811)“, u: Vojna krajina. Povijesni pregled - historiografija - rasprave (ur. Dragutin Pavličević), Sveučilišna naklada Liber - Centar za povijesne znanosti Sveučilišta u Zagrebu, Odjel za hrvatsku povijest, Zagreb 1984., 319-330.

"O Srbima u hrvatskim zemljama u Mrkaljevo doba", Književnost, 34/1984., knj. 77, sv. 4-5, 520-534. 
"O jugoslavenskom odgoju omladine", u: Mladi i nacionalizam (ur. Dušan Davidović), Beograd 1984., 257-271.

Prikaz istraživanja „Nacionalno i jugoslavensko od početka 19. stoljeća do suvremenog doba u srednjoškolskim udžbenicima povijesti“, koje su realizirali beogradski i zagrebački sveučilišni nastavnici mr. Marijan Maticka, Ivan Obradović, Drago Roksandić, Nikša Stančıć i Đorđe Đ. Stanković u suradnji sa sljedećim studenticama i studentima s Filozofskog fakulteta Sveučilišta u Zagrebu i Filozofskog fakulteta Univerziteta u Beogradu: Jasna BALAšKo, Borislav BııELı́, Vera Bosıı,, Narcisa BrezinšČAK, Božena Buljan, Milosija Ćurlić, Zoran DimitrIJević, Iskra Ivelıć, Ljiljana JelisavČıć, Tijana Jerinić, Jelena Jurić, Ivan Kardum, Snežana Marinković, Goran Popović, Tomislav Radonić, Slavica Radovanović, Ivica Skenderović, Dubravka Stojanović, Vlado Valentić i Jasmina Vukadin (260).

„Marksistička historiografija i tradicionalistička svijest", u: Historija i suvremenost. Idejne kontroverze (ur. Stipe Pojatina), Centar CK SKH za idejno-teorijski rad „Vladimir Bakarić" - ČGP „Delo“, Zagreb 1984., 63-68.

\section{5.}

„Savremenost i istorijska svest", Marksistička misao, 2/1985., 78-86.

"Osnovna tema: Suvremenost i istorijska svest“" (Andrej Mıtrović; Milan Matıć; Predrag VRanickl; Todor KulıÍ́; Predrag Matvejević; Rene Lovrenčlć; Milovan Mitrović; Sima Ćırković; Božidar Jakšıć; Dragoljub Mićunović; Drago Roksandić; Branko Petranović; Đorđe Đ. Stanković; Nikša Stančić; Dušan Jović; Dragomir GaJević; Zoran Lakić; Vladimir MiLanović (3-193)

„Povijesno mišljenje između antropologije i socijalne historije“, Naše teme, 29/1985., br. 4-6, 385-390.

„Iz ranije prošlosti kotara Donji Lapac", u: Kotar Donji Lapac u narodnooslobodilačkom ratu 1941-1945. (ur. Gojko Vezmar; Đuro Zatezalo), Historijski arhiv u Karlovcu 14, Karlovac 1985., 1005-1039.

"O političko-historijskim istraživanjima nacionalnog pitanja“, Sveske [Institut za proučavanje nacionalnih odnosa, Sarajevo], 3/1985., br. 11-12, 219-225.

Tema broja: „Naša novija literatura o nacionalnim odnosima“ (149-334)

\section{6.}

"Jugoslavenstvo prije stvaranja Jugoslavije", u: Istoriografija, marksizam i obrazovanje. Nedjelja marksističkih rasprava '85 (ur. Milenko Marković; Vukašin Stambolić; Drago Roksandić), Izdavački centar Komunist, Beograd 1986., 153-159.

"Jugoslovanstvo pred nastankom Jugoslavije“, Borec. Revija za zgodovino NOB in ohranjanje revolucionarnih tradicij, 37/1985, br. 10-11, 546-549. Slovenski.

"Jugoslavenstvo u suvremenim udžbenicima povijesti u Jugoslaviji“, u: Istoriografija, marksizam i obrazovanje. Nedjelja marksističkih rasprava '85 (ur. Milenko Marković; Vukašin Stambolić; Drago Roksandić), Izdavački centar Komunist, Beograd 1986., 223-229.

\section{7.}

„Francusko imperijalno ilirstvo u Ilirskim pokrajinama (1809-1813)“, Jugoslovenski istorijski časopis, 22/1987., br. 3, 17-37.

„/Diskusija/“, u: Srbija 1916. godine, Istorijski institut Beograd: Zbornik radova, knj. 5, Istorijski institut, Beograd 1987., 374-375. 
„Bilješka o jugoslavenskoj omladini osamdesetih godina“, Pogledi. Časopis za društvena pitanja, 17/1987., br. 1, 82-86.

Tema broja: „Jugoslavenska omladina između apatije i političkog subjektiviteta“ (19-112)

„O otvorenim pitanjima jezičke politike u SR Srbiji“, Marksistička misao, 5-6/1987., 96-103.

\section{8.}

„Između imaginacije i realnosti. Prva banska regimenta u prvoj polovini 19. stoljeća“, u: Glina. Glinski kraj kroz stoljeća (ur. Drago Roksandić; Mira Kolar-Dimitrijević), Glina 1988., 45-57.

„Vuk Karadžić, ilirci i proces srpske nacionalne integracije u hrvatskim zemljama“, u: Naučni sastanak slavista u Vukove dane, vol. 17/4, Međunarodni slavistički centar, Beograd 1988., 119-128.

„Drago Roksandićc, u: Međunarodni naučni skup Vuk Karadžić i njegovo delo u svome vremenu i danas. Rezimea, Međunarodni slavistički centar - Filološki fakultet Beograd, Beograd 1987., 76. „Vuk Karadžić, ilirci i proces srpske nacionalne integracije u hrvatskim zemljama“, Vjesnik, 22. 23. 11. 1987.

„O jeziku između nacije i komunikacije“, Marksistička misao, 1/1988., 35-39.

\section{9.}

Drago RokSANDIĆ; Ivan OBRADOvić, "O popisu žumberačkih uskoka iz 1551. godine“, u: Vojne krajine u jugoslovenskim zemljama u Novom veku do Karlovačkog mira 1699. Zbornik radova sa naučnog skupa održanog 24. i 25. aprila 1986. (ur. Vasa Čubrilović), SANU, Beograd 1989., 125-146.

„L'image de la Révolution française parmi les Serbes et les Croates. (1789-1799)“, u: L'image de la France révolutionnaire dans les pays et les peuples de l'Europe Centrale et du Sud-Est (ur. Georges Castellan), Centre d'Étude des Civilisations de l'Europe Centrale et du Sud-Est - Institut National des Langues et Civilisations Orientales, Paris 1989., 91-102. Francuski.

"Colloque international tenu à Paris du 13 au 15 octobre 1988“

„Hrvatske zemlje, francuska revolucija i Napoléonski ratovi / Les pays croates, la révolution française et les guerre de Napoléon I.", u: Hrvatske zemlje i francuska revolucija. Katalog izložbe (ur. Jasna Tomičić), Povijesni muzej Hrvatske, Zagreb 1989., 13-30. Hrvatski i francuski.

"'Glas Slovenaca, Hrvata i Srba' o stvaranju jugoslavenske države 1918. godine“, u: Stvaranje jugoslovenske države 1918. godine (ur. Vasa Čubrilović), Beograd 1989., 465-471.

„Hrvati i Srbi u hrvatskim zemljama godine 1861. između etnosa, naroda i nacije“, Migracijske teme, 5/1989., br. 2-3, 131-143.

"Agrarne ideologije i teorije modernizacije u Jugoslaviji od 1918. do 1929“, Naše teme, 33/1989., br. 5, 1135-1149.

"Jezička ravnopravnost i uzajamnost“, Naše teme, 33/1989., br. 4, 680-683.

"Naša tema: Jezik i politika“ (655-724)

„'Desničini susreti'. Prijedlog programa znanstvenih rasprava“, Naše teme, 33/1989., br. 4, 725-730. 
Ante Bežan; Drago Roksandić; Zorica Stipetić, „Prijedlog koncepcije časopisa 'Dijalozi'“, Naše teme, 33/1989., br. 10, 2696-2699.

\section{0.}

„Rado Vučinić, izaslanik srpskih ustanika na dvoru Napoléona I.“, u: Naučni skup „Jugoslovensko-francuski odnosi. Povodom 150 godina od otvaranja prvog francuskog konzulata u Srbiji“" (ur. Slavenko Terzić), Istorijski institut Beograd: Zbornik radova, knj. 10, Istorijski institut, Beograd 1990., 56-66.

„Tradicija vojnokrajiškog prava i Ostrožinski pravilnik", u: Ostrožinski pravilnik 14. XII. 1941. Materijali s naučnog skupa u Vrginmostu, 15. decembra 1989. (ur. Đuro Zatezalo), Historijski arhiv u Karlovcu - Skupština općine Vrginmost, Zbornik 21, Karlovac 1990., 109-116.

„ZAVNOH 1943. u dokumentima CK KPJ i CK KPH", u: ZAVNOH 1943-1944. Materijali s naučnog skupa održanog u Otočcu 2. i 3. oktobra 1989. (ur. Đuro Zatezalo), Historijski arhiv u Karlovcu - Institut za suvremenu povijest u Zagrebu, Zbornik 22, Karlovac 1990., 280- 291.

„Serben, Kroaten und Mitteleuropa“, u: Standort Österreich. Über Kultur, Wirtschaft und Politik im Wandel (ur. Gerd Bacher; Karl Schwarzenberg; Josef Taus), Styria Verlag, Graz 1990., 795-812. Njemački.

„Srbi, Hrvati i Srednja Evropa“, Odjek, br. 19-20, 1. - 31. 10. 1990., 1, 11.

„Szerbek, Horvatok es Kozep-Europa“, Hiany, veljača 1992., 26-29. Mađarski.

\section{1.}

„Hrvatska 1941. Rasprava u povodu 50. obljetnice početka antifašističke borbe. (...) Drago Roksandić", Časopis za suvremenu povijest, 23/1991., br. 1-3, 94-97.

Sudionici: Ivan Jelć; Ljubo Boban; Vladimir Đuro DeGan; Darko Bekić; Gordana Vlajčćć; Zorica Stipetić; Mihael Sobolevski; Drago Roksandić; Dušan Bilandžlć; Petar Strčıć; "Summary. The Round Table: Croatia in 1941" (103-104)

„Srbi u Hrvatskoj. Pitanja o pola stoljeća povijesti 1941-1990“, u: Položaj naroda i međunacionalni odnosi u Hrvatskoj. Sociologijski i demografski aspekti (ur. Štefica Bahtijarević; Mladen Lazić), Institut za društvena istraživanja Sveučilišta u Zagrebu, Zagreb 1991., 11-21.

„Kordunska 'Slunjska ploča' - prostor na granicama, migracije bez kraja“, u: Vanjske migracije i društveni razvitak (ur. Milan Mesić i sur.), Institut za migracije i narodnosti Sveučilišta u Zagrebu, Zagreb 1991., 62-77.

"Kein historischer Konflikt“, Ost-West-Gegeninformationen, 3/1991., br. 7-8, 11-14.

"Demokratie in 'Jugoslawien': Der Hoffnung winziges Orchester", Transit. Europäische Revue, 3/(Winter) 1991. - 1992., Heft 3, 159-172.

\section{2.}

"Croatie. L'espoir", u: L'Allemagne vue d'ailleurs (ur. Michel Korinmann), Paris 1992., 227-239. Francuski. 
„Chancen mit zahllosen Variablen. Die Möglichkeiten einer kroatisch-serbischen Verständigung in Kroatien“, u: Krieg in Europa. Analysen aus dem ehemaligen Jugoslawien (ur. Johann Gaisbacher; Karl Kaser; Christian Promitzer; Barbara Sax; Johann Schögler), Studienreihe der „Ost-West-Gegeninformationen“, I, Graz 1992., 126-204. Njemački. "Myths of Historical Conflict in Yugoslavia", Labour Focus on Eastern Europe. A Review of European Affairs, 41/1992., br. 10-11, 18-20. Engleski.

\section{4.}

„Drago Roksandić", u: „Okrugli stol Srbi i Hrvati. Zagreb, 20-22. studeni 1993.“, Erasmus. Časopis za kulturu demokracije, 5/1994., 21-24, 44.

„Pravoslavna crkvena općina na području Gradeca između Patenta o toleranciji 1781. i revolucije 1848/9. godine“, u: Zagrebački Gradec 1242-1850. (ur. Ivan Kampuš; Lujo Margetić; Franjo Šanjek), Grad Zagreb, Zagreb 1994., 277-292.

"O 'herojima' i postanku Sjedinjenih Američkih Država", Politička misao, 31/1994., br. 2, 63-69.

„Toynbee, Arnold Joseph“, u: Velikani naše epohe. Ličnosti i djela druge polovice XX. stoljeća (ur. Ratko Vince), Treći program Hrvatskog radija, Zagreb 1994., 622-625.

"Nationale Konflikte in Titos Jugoslawien - ein Tabu?", u: Tabu und Geschichte. Zur Kultur des kollektiven Erinnerns (ur. Peter Bettelheim; Robert Streibel), Picus Verlag, Wien 1994., 100-128. Njemački.

"Nacionalni sukobi u Titovoj Jugoslaviji - tabu?", Ljetopis Dvije hiljade druge, 2002., 205-224.

"O opstojnosti novih europskih zemalja“, u: Međunarodni položaj novih europskih zemalja (ur. Nada Švob Đokić), Institut za razvoj i međunarodne odnose, Zagreb 1994., 3-17.

\section{5.}

„Pavao Ritter Vitezović u srpskoj kulturi“, Prosvjeta. Narodni srpski kalendar za godinu 1995. (ur. Drago Kekanović; Čedomir Višnjić), SKD Prosvjeta, Zagreb 1995., 73-77. „Austroslavistische Tendenzen bei den Serben“, u: Der Austroslavismus. Ein verfrühtes Konzept zur politischen Neugestaltung Mitteleuropas (ur. Andreas Moritsch), Schriftenreihe des Internationalen Zentrums für Nationalismus und Minderheitenforschung, Band 1, Böhlau Verlag, Wien - Köln - Weimar 1995., 138-146. Njemački.

"1848 - Revolution oder Rebellion in Ungarn“, u: Revolutionen in Ostmitteleuropa 17891989. Schwerpunkt Ungarn (ur. Karlheinz Mack), Verlag für Geschichte und Politik Wien - R. Oldenburg Verlag München, Wien - München 1995., 70-82. Njemački.

„Völkerkerker, Vielvölkerstaat, neue Nationalstaaten. Illusionen und Realitäten der kleinen Völker Mitteleuropas. Illusionen und Realitäten der kleinen Völker Mitteleuropas", Mitteleuropa II. Was - Zeitschrift für Kultur und Politik, 79/1995., 31-42. Njemački. Suradnici: Daniela StrIGl; Ferenc Glatz; Eduard Goldstücker; Péter Hanák; Helmut KonRad; Drago RoKSANDić. Njemački.

„O Bogišiću danas“, Dubrovnik. Časopis za književnost, nauku i umjetnost, 6/1995., br. 1, 153-158. 
"Shifting References: Celebrations of Uprisings in Croatia, 1941-1991", Resistance and Collaboration in Europe, 1939-1945: Experience, Memory, Myth, and Appropriation. East European Politics and Societies, 9/(Spring) 1995., br. 2, 256-271. Engleski.

„Ustanak u Hrvatskoj u ljeto 1941.: Kultura ili kulture pamćenja od 1945. do 1991. godine?", u: Spomenica Renea Lovrenčića (ur. Damir Agičić; Drago Roksandić; Tvrtko Jakovina), Filozofski fakultet Sveučilišta u Zagrebu - FF press, Zagreb 2016., 307-321.

\section{6.}

"L'historiographie croate apres 1989", u: Histoire et pouvoir en Europe mediane (ur. Antoine Marès), Collection „Aujourd'hui I'Europe“, L'Harmattan, Paris 1996., 273-281. Francuski.

„La storiografia croata doppo il 1989“, u: I muri della storia. Storici e storiografia dalle dittature alle democrazie 1945-1990 (ur. Gustavo Corni), Università di Trieste, Quaderni del Dipartimento di Storia 2, Trieste 1996., 211-218. Talijanski.

„Lujo Matutinović (1765. - 1844.), istraživački izazovi životopisa jednoga nepoznatog maršala", Narodna umjetnost. Hrvatski časopis za etnologiju i folkloristiku, 33/1996., br. 2, 211-238. /"U čast Dunji Rihtman-Auguštin“/

„Résumé: Lujo Matutinović (1765-1844): Les défis de recherche de la biographie d'un maréchal inconnu“ (238)

"Lujo Matutinović (1765-1844): Le sfide di una ricerca sulla biografia di un ignoto maresciallo", Atti del Centro di Ricerche Storiche di Rovigno, 29/1999., 373-400, 420-421. Talijanski.

Prilog: Lujo Matutinović, Notice Géographique, Politique, Civile et Militaire de l'Istrie, des Isles de Quarnero et de celles de la Dalmatie (prijepis izvornika: Florence Fabijanec) (401-419)

\section{7.}

"Religious Tolerance and Division in the Krajina: The Croatian Serbs of the Habsburg Military Border", Christianity and Islam in Southeastern Europe. East European Studies. Occasional Paper, 47/1997., 49-82. Engleski.

Autori: Charles FrazeE; Eve Levin; Drago Roksandić

„Vjerske podjele i (ne)snošljivosti u Vojnoj krajini“, Ljetopis SKD „Prosvjeta”, 2/1997., 62-101.

„Ethnic Conflicts in Croatia?", u: Ethnic Conflicts and Civil Society. Proposals for a New Era in Eastern Europe (ur. Andreas Klinke; Ortwin Renn; Jean-Paul Lehners), Ashgate, Aldershot - Brookfield USA - Singapore - Sydney 1997., 115-126. Engleski.

„Minorities, Religions: Serbs", u: Multicultural Reality and Perspectives in Croatia (ur. Vjeran Katunarić), Interkultura, Zagreb 1997., 81-95. Engleski.

„Srbi u Hrvatskoj. Skica za sintezu povijesnog iskustva“, Prosvjeta. Novine za kulturu, 3/1996., br. 19/20, 16-19; 9/2002., br. 50, 18-21. (Drugi put objavljeno u pedesetom, jubilarnom broju Prosvjete.)

„Erinnern oder Vergessen?", u: Verschwiegenes Serbien. Stimmen für die Zukunft? (ur. Irena Šlosar), Wieser Verlag, Klagenfurt - Salzburg 1997., 265-278. Njemački.

\section{8.}

"Alexis de Tocqueville i 'exceptionalism' američke povijesti", u: Alexis de Tocqueville o američkoj povijesti (ur. Drago Roksandić; Maja Brkljačić), Filozofski fakultet Sveučilišta 
u Zagrebu, Zavod za hrvatsku povijest - United States Information Service, Zagreb 1998., 148-195.

"Ideologien, Mentalitäten und Mythen in den Werken Miroslav Krležas", u: Das Bild vom Anderen. Idenitäten, Mentalitäten, Mythen, und Stereotypen in multiethnischen europäischen Regionen (ur. Valeria Heuberger; Arnold Suppan; Elisabeth Vyslonzil), Peter Lang. Europäischer Verlag der Wissenschaften, Frankfurt am Main - Berlin Bern - New York - Paris - Wien 1998., 197-207. Njemački.

„Das menschliche Antlitz der Kriegsopfer. Politische Justiz und Zivilgesellschaft", u: Keine "Abrechnung". NS-Verbrechen, Justiz und Gesellschaft in Europa nach 1945 (ur. Claudia Kuretsidis-Haider; Winfried R. Garscha), Bundesministerium für Justiz, Dokumentationsarchiv des österreichischen Widerstandes - Akademische Verlagsanstalt, Leipzig - Wien 1998., 384-388. Njemački.

„The Triplex Confinium. International Research Project: Objectives, Approaches and Methods", u: Microhistory of the Triplex Confinium. International Project Conference Papers (Budapest, March 21-22, 1997) (ur. Drago Roksandić), Central European University, Institute on Southeastern Europe, Budapest 1998., 7-25. Engleski.

„Triplex Confinium“, Ljetopis SKD „Prosvjeta”, 3/1998., 157-174.

„TRIPLEX CONFINIUM. Međunarodni istraživački projekt: ciljevi, pristupi, metodi“, Prilozi Instituta za istoriju, 30/2001., 43-61.

Drago Roksandić; Sanja LazaniN, „J. W. Valvasor and J. Rabatta on the Croatian Military Border in 1689 and 1719. Stereotypes and Mentality in the Triple Frontier Comparative Perspective", u: Microhistory of the Triplex Confinium. International Project Conference Papers (Budapest, March 21-22, 1997) (ur. Drago Roksandić), Central European University, Institute on Southeastern Europe, Budapest 1998., 89-110. Engleski.

"Croatia", u: A Guide to East-Central European Archives. Austrian History Yearbook, 29/1998., dio 2., 11-22. Engleski.

\section{9.}

"Historiografija o hrvatskom ranom novom vijeku u europskom kontekstu“, Historijski zbornik, 52/1999., 171-177.

Predavači plenarnih sjednica: Nenad CAMBI; Radoslav KATIČIĆc; Neven BudAK; Miroslav BertošA; Mirko Valentić; Nikša Stančićc; Mirjana Gross; Nada Kisı́c Kolanović; Marijan Maticka; Neven Budak; Drago Roksandić; Božena VRanjěšŠoljan; Hrvoje MatKović

Vidjeti: I. kongres hrvatskih povjesničara. Hrvatski nacionalni i državni kontinuitet. Knjiga sažetaka, Hrvatski nacionalni odbor za povijesne znanosti - Hrvatski institut za povijest - Odsjek za povijest Filozofskog fakulteta Sveučilišta u Zagrebu - Društvo za hrvatsku povjesnicu, Zagreb 1999., 24.

„Dinara kao ekohistorijski problem. Ranonovovjekovni kartografski aspekti“, Radovi Zavoda za hrvatsku povijest Filozofskog fakulteta Sveučilišta u Zagrebu, 32-33/1999. - 2000., 333-343.

„Dinara kao ekohistorijski problem. Ranonovovjekovni kartografski aspekti”, Prosvjeta. Novine za kulturu, 7/2000., br. 41/42, 34-41.

"Hrvatsko i ugarsko reformsko plemstvo Osamnaestog stoljeća: povijesne usporedbe", u: Nikola Škrlec Lomnički 1729.-1799. Sv. 2. (ur. Eugen Pusić et al.), HAZU - Hrvatski državni arhiv - Filozofski fakultet Sveučilišta u Zagrebu - Pravni fakultet Sveučilišta u Zagrebu, Zagreb 1999., 3-22. 
„Ban Josip Jelačić (1801-1859). Mitovi u promjenama i trajanjima“, u: Zbornik Mirjane Gross. U povodu 75. rođendana (ur. Ivo Goldstein; Nikša Stančić; Mario Strecha), Filozofski fakultet Sveučilišta u Zagrebu, Zavod za hrvatsku povijest, Zagreb 1999., 105-115.

„Mitovi u promjenama i trajanju: ban Josip Jelačić (1801 - 1859.)“, Prosvjeta. Novine za kulturu, 6/1999., br. 36, 26-30.

\section{0.}

"Stojan Janković in the Morean War, or of Uskoks, Slaves and Subjects", u: Constructing Border Societies on the Triplex Confinium (ur. Drago Roksandić; Nataša Štefanec), Central European University History Department, Working Paper Series 4, Budapest 2000., 239-288. Engleski.

„Stojan Janković u Morejskom ratu ili o uskocima, robovima i podanicima“, Ljetopis SKD „Prosvjeta", 5/2000., 125-188.

„Stojan Janković nella guerra di Morea ovvero degli Uscocchi, degli schiavi e die sudditi”, Atti del Centro di Ricerche Storiche di Rovigno, 30/2000., 315-390. Talijanski.

\section{1.}

"Zapisi o temama iz povijesti Gospića“, Prosvjeta. Novine za kulturu, 8/2001., br. 45/46, 13-17.

\section{2.}

"Shifting Boundaries, Clientelism and Balkan Identities", u: Political Uses of the Past. The Recent Mediterranean Experience (ur. Jacques Revel; Giovanni Levi), Frank Cass, London - Portland Or. 2002., 43-48. Engleski.

„Shifting Boundaries, Clientelism and Balkan Identities", Mediterranean Historical Review, 16/2001., br. 1, 43-48. Engleski.

„Ottomans, Venetians and Habsburgs: 'Triplex Confinium'“, u: The Turks. Part 3. The Ottomans (ur. Hasan Celal Güzel; Cem Oğuz; Osman Karatay; Murat Ocak), Yeni Türkiye, Ankara 2002., 415-425. Engleski.

„Srbi (u Hrvatskoj) u hrvatskoj i srpskoj historiografiji: problemi usporedbe dvije interpretacijske tradicije", u: Dijalog povjesničara - istoričara 5: Herceg Novi, 2.-4. ožujka 2001. (prir. Igor Graovac; Hans-Georg Fleck), Friedrich Naumann Stiftung, Zagreb 2002., 211-230.

„Evropske šanse Hrvatske i Srbije“, Prosvjeta. Novine za kulturu, 9/2002., br. 49, 8-9.

\section{3.}

„Hrvatska vojna krajina u austrijskoj i francuskoj geostrategiji (1789.-1815.). Usporedba“, u: Zbornik Ivana Mimice u povodu 70. rođendana (ur. Živko Bjelanović; Šime Pilić), Biblioteka Školskog vjesnika 1, Split 2003., 253-273.

„Der Parlamentarismus von 1848 in der politischen Kultur Kroatiens: Rezeptionen seit 1990", u: 1848. Ereignis und Erinnerung in den politischen Kulturen Mitteleuropas (ur. Barbara Haider; Hans Peter Hye), Österreichische Akademie der Wissenschaften, 
Philosophisch-Historische Klasse, Historische Kommission, Zentraleuropa Studien, Band 7, Verlag der Österreichischen Akademie der Wissenschaften, Wien 2003., 203-215. Njemački.

"Niccolò Tommaseo: prospettiva storica sulle appropriazione culturali e ideologico-nazionali croate e serbe", u: Niccolò Tommaseo: popolo e nazioni - italiani, corsi, greci, illirici. Atti del Convegno internazionale di Studi nel bicentenario della nascita di Niccolò Tommaseo, Venezia, 23-25 gennaio 2003, Roma - Padova 2004., 625-639. Talijanski. „Nikola Tommaseo (1802.-1874.) u povijesnoj perspektivi: hrvatske i srpske kulturne i nacionalnoideologijske aproprijacije“, u: Zbornik Mire Kolar-Dimitrijević. Zbornik radova povodom 70. rođendana (ur. Damir Agičić), Filozofski fakultet Sveučilišta u Zagrebu, Odsjek za povijest - FF press, Zagreb 2003., 179-187.

„Nikola Tommaseo u povijesnoj perspektivi: hrvatske i srpske kulturne i nacionalnoideologijske aproprijacije“, Prosvjeta. Novine za kulturu, 10/2003., br. 57, 27-31.

"Niccolò Tommaseo (1802-1874): prospettiva storica sulle appropriazioni culturali e ideologico-nazionali croate e serbe“, Atti del Centro di Ricerche Storiche di Rovigno, 38/2008., 161-177. Talijanski.

„Dell'Italia nella paura e nella speranza. L'Italia nell'immaginazione dei Serbi nelle terre croate durante la guerra italo-turca (1911-1912)“, Atti del Centro di Ricerche Storiche di Rovigno, 33/2003., 399-424. Talijanski.

"O Italiji, u strahu i nadi. Italija u političkoj imaginaciji Srba u hrvatskim zemljama u vrijeme talijansko-turskog rata“, Prosvjeta. Novine za kulturu, 9/2002., br. 52, 18-24.

"André Blanc 1922. - 1977. Hommage“, Prosvjeta. Novine za kulturu, 10/2003., br. 60, $15-20$.

"Ognjeslav Utješenović i Baltazar Bogišić: ljudi i pisma", Ljetopis Dvije hiljade treće Srpskog kulturnog društva Prosvjeta, 8/2003., 261-270.

„Povijesno sjećanje ili povijesni zaborav? Prilozi raspravi o političkoj kulturi u Srbiji“, u: Zbornik Janka Pleterskega (ur. Oto Luthar; Jurij Perovšek), Zgodovinski inštitut Milka Kosa Založba ZRC, ZRC SAZU, Ljubljana 2003., 623-628.

„Povijesno sjećanje ili povijesni zaborav. Prilozi raspravi o političkoj kulturi u Srbiji“, Prosvjeta. Novine za kulturu, 9/2002., br. 54, 23-25.

\section{4.}

„Interkulturalizam u nastavi povijesti: pristupi, koncepti i nastavna praksa“, Povijest u nastavi, 2/2004., br. 2/4, 283-304.

„Imperijalna granica i sanitarni kordon u 18. stoljeću“, Ljetopis Dvije hiljade četvrte Srpskog kulturnog društva Prosvjeta, 9/2004., 123-141.

\section{5.}

„Anketa 'Pripadati ili ne pripadati'“, Ljetopis Dvije hiljade pete Srpskog kulturnog društva Prosvjeta, 10/2005., 42-45.

"Zavičajna povijest: pojmovni izazovi", Školski vjesnik. Časopis za pedagoška i školska pitanja, 54/2005., br. 3-4, 195-204.

Tema broja: „Zavičaj i zavičajnost u znanosti i obrazovanju“ (183-279)

„MOSTOVI: revitalizacija Kule Stojana Jankovića i područja sela Islam Grčki, Islam Latinski i Kašić: sažetak projekta", Prosvjeta, 12/2005., br. 70, 22-25. 


\section{6.}

"Zavičajna povijest: pojmovni izazovi“, u: Zavičajna povijest u interkulturalnom kontekstu. Prvi hrvatski simpozij o nastavi povijesti (Opatija, od 27. do 29. studenoga 2003.). Zbornik (ur. Marijana Marinović; Drago Roksandić), Filozofski fakultet Sveučilišta u Zagrebu, Odsjek za povijest - Zavod za školstvo Republike Hrvatske - Društvo za hrvatsku povjesnicu Rijeka - Povijesno društvo Rijeka - Povijesno društvo otoka Krka - FF press, Zagreb 2006., 25-32.

„Književnik, književni opus i mogućnosti historiografskih interpretacija: pokušaj 'egohistorije' Vladana Desnice (Zadar, 1905. - Zagreb, 1964.)“, u: Vojetov zbornik. Med Srednjo Evropo in Sredozemljem (ur. Sašo Jerše; Darja Mihelič; Peter Štih), Založba ZRC, ZRC SAZU, Ljubljana 2006., 635-645.

„Književnik, književni opus i mogućnosti historiografskih interpretacija: pokušaj 'egohistorije' Vladana Desnice (Zadar, 1905. - Zagreb, 1964.)“, Književna republika, IV/2006., br. 3-4, 13-24.

„Pamćenje i kultura povijesnog mišljenja - baština hrvatskog antifašizma 1945-2005.", u: 1945 - razdjelnica hrvatske povijesti: Zbornik radova sa znanstvenog skupa održanog u Hrvatskom institutu za povijest u Zagrebu 5. i 6. svibnja 2006. (ur. Nada Kisić Kolanović; Mario Jareb; Katarina Spehnjak), Hrvatski institut za povijest, Zagreb 2006., 37-46.

"O tragediji, traumi i katarzi: Srbi u jasenovačkom logoru, 1941.-1945. godine“, u: Spomen područje - Memorial Site Jasenovac (ur. Tea Benčić-Rimay), Javna ustanova Spomen-područje Jasenovac, Jasenovac 2006., 72-105.

„Srbi u Jasenovačkom logoru: o tragediji, traumi i katarzi“, Prosvjeta. Novine za kulturu, 14/2007., br. $78,18-25$.

\section{7.}

"Dalmatinska zagora u ranome novom vijeku: pitanja za raspravu“, u: Dalmatinska zagora - nepoznata zemlja. Katalog izložbe (ur. Joško Belamarić; Marko Grčić), Ministarstvo kulture Republike Hrvatske - Galerija Klovićevi dvori, Zagreb 2007., 185-196.

„Posavska krajina/granica od 1718. do 1739. godine“, Ekonomska i ekohistorija. Časopis za gospodarsku povijest i povijest okoliša / Economic- and Ecohistory. Journal for Economic History and Environmental History, 3/2007., br. 3, 62-82.

„'Others' and Violence in Croatia in 1755: Classes, Confessions and Ethnies in Literar Perceptions of Conflicts", u: National Stereotypes. Correct Images and Distorted Images (ur. Bianca Valota), Slavica 12, Edizioni dell'Orso, Alessandria 2007., 87-114. Engleski. „'Drugi' i nasilje u Hrvatskoj 1755. godine: staleži, konfesije i etnosi u literarnim percepcijama socijalnog konflikta", u: Svoj i tuđ. Slika drugog u balkanskim i srednjeevropskim književnostima. Zbornik radova (ur. Miodrag Maticki), Institut za književnost i umetnost, Beograd 2006., 137-158.

"Controversies on German Cultural Orientation in the 'Croatian National Revival': German Language and Culture in Croatian Everyday Life, 1835-1848“, u: The Germans and the East (ur. Charles Ingrao; Franz A. J. Szabo), Perdue University Press, West Lafayette, Indiana 2008., 129-146. Engleski.

„Kontroverze o njemačkoj kulturnoj orijentaciji u hrvatskom narodnom preporodu: njemački jezik u hrvatskoj svakodnevici, 1835.-1848." , Historijski zbornik, 40/2007., 65-81. 
Phantom der Freiheit. Literaturzeitschrift / Fantom slobode. Književni časopis, 1-2/2008., 93-172. Njemački.

Izbor članaka izvorno objavljenih na njemačkom: Drago RoksAnDIĆ, „Serben, Koaten und Mitteleuropa“ (95-110); "Ideologien, Mentalitäten und Mythen in den Werken Miroslav Krležas" (111-127); "Nationale Konflikte in Titos Jugoslawien - ein Tabu?" (128-158); "Demokratie in 'Jugoslawien': Der Hoffnung winziges Orchester" (159-172)

„'Bratstvo i jedinstvo' u političkom govoru hrvatskih/jugoslavenskih komunista 1919.-1945. godine“, u: Bratstvo i jedinstvo - suživot (ur. Tomislav Badovinac), Savez društava "Josip Broz Tito" Hrvatske, Zagreb 2007., 43-60.

"'Bratstvo i jedinstvo' u političkom govoru jugoslavenskih komunista 1919 - 1945. godine“, u: Tito - viđenja i tumačenja. Zbornik radova (ur. Olga Manojlović-Pintar; Sanja Petrović Todosijević; Mile Bjelajac), Institut za noviju istoriju Srbije - Arhiv Jugoslavije, Beograd 2011., 28-42.

"Les quatre destructions de Sarajevo", Cité. Philosophie, Politique, Histoire, 32/2007., 17-28. Francuski.

"Destrukcija Sarajeva 1992. - 1994. u historijskoj perspektivi“, u: Bertošin zbornik. Zbornik u čast Miroslava Bertoše, knj. 3 (ur. Ivan Jurković), Sveučilište Jurja Dobrile u Puli - Državni arhiv u Pazinu, Pula - Pazin 2013., 391-399.

„Destrukcija Sarajeva 1992-1994. u historijskoj perspektivi“, Ljetopis crnogorski, 5/2010. - 2011., $47-54$.

\section{9.}

"The Dinaric Vlachs/Morlachs in the Eastern Adriatic from the Fourteenth to the Fifteenth Centuries: How Many Identities?", u: Balcani occidentali, Adriatico e Venezia fra XIII e XVIII secolo - Der westliche Balkan, der Adriaraum und Venedig (13. - 18. Jahrhundert) (ur. Gherardo Ortalli; Oliver Jens Schmitt), Istituto Veneto di Scienze, Lettere ed Arti - Verlag der Österreichischen Akademie der Wissenschaften, Venezia - Wien 2009., 271-285. Engleski.

„Dinarski Vlasi/Morlaci od 14. do 16. stoljeća: koliko identiteta“, u: Spomenica Josipa Adamčeka (ur. Drago Roksandić; Damir Agičić), Filozofski fakultet Sveučilišta u Zagrebu, Odsjek za povijest - FF press, Zagreb 2009., 209-219.

„L'Europe et ses frontières multiples dans le Sud-Est: problèmes et approches - Europa i njene višestruke jugoistočnoeuropske granice: problemi i pristupi“, u: La perception de l'Europe. Table ronde organisée par l'ambassade de France dans le cadre de la présidence française de I'UE - Percepcija Europe (ur. Dražen Katunarić), Litteris, Zagreb 2009., 52-63, 156-166. Francuski i hrvatski (dvojezično izdanje).

2010.

Drago Roksandić; Tomislav BranĐolica; Marko Lovrić; Nikolina Sarić; Filip ŠImetin Šegvić, "Filozofski fakultet u poplavi 1964. godine: sjećanja i dokumenti", Hrvatske vode. Časopis za vodno gospodarstvo, 18/2010., br. 73, 241-248.

„Zrinska gora u ranome novom vijeku: kartografske percepcije“, Ekonomska i ekohistorija. Časopis za gospodarsku povijest i povijest okoliša / Economic- and Ecohistory. Journal for Economic History and Environmental History, 6/2010., br. 6, 8-26.

„Rade Bosnić: skica za biobibliografiju“, Ljetopis Dvije hiljade desete, 15/2010., 158-177. 
„O Vladanu Desnici i 'Desničinim susretima', u: Desničini susreti 2005.-2008. Zbornik radova (ur. Drago Roksandić; Ivana Cvijović Javorina), Biblioteka Desničini susreti, sv. 3, Filozofski fakultet Sveučilišta u Zagrebu - Plejada, Zagreb 2010., 255-306.

„Les discours croates de l'antifascisme, entre mémoire et oubli (1941-2005)“, u: Mémoire et histoire en Europe centrale et orientale (ur. Daniel Baric; Jacques Le Rider; Drago Roksandić), Collection „Histoire“, Presses universitaires de Rennes, Rennes 2010., 239-247. Francuski.

"Diskursi hrvatskog antifašizma i izazovi povijesnog pamćenja i zaborava (1941. - 2005.)“, u: Zbornik Nikše Stančića (ur. Iskra Iveljić), Filozofski fakultet Sveučilišta u Zagrebu, Zavod za hrvatsku povijest - FF press, Zagreb 2011., 361-368.

\section{1.}

„Drava u očima jozefinista“, Ekonomska i ekohistorija. Časopis za gospodarsku povijest $i$ povijest okoliša / Economic- and Ecohistory. Journal for Economic History and Environmental History, 7/2011., br. 7, 18-37.

„Drava u očima jozefinista”, Ekohistorija rijeke Drave. Zborniks međunarodnog znanstvenog skupa (ur. Dragutin Feletar; Hrvoje Petrić; Drago Roksandić), Povijesno društvo Koprivnica - Društvo za hrvatsku ekonomsku povijest i ekohistoriju, Koprivnica 2011., 18-37.

„Konfliktne strategije u proizvodnji prostora Banske krajine u XVIII stoljeću: pogledi ‘odozdo' i 'odozgo'“ , u: Prostorno planiranje u Jugoistočnoj Evropi (do Drugog svetskog rata) (ur. Bojana Miljković-Katić), Istorijski institut - Balkanološki institut SANU - Geografski fakultet Univerziteta u Beogradu, Beograd 2011., 77-116.

„Vladimir Ardalić o sebi i 'Drugima' - 'Drugi' i Ardalić", Godišnjak Titius, 4/2011., br. 4, 19-56.

„Zagrebački Filozofski fakultet u revolucionarnoj tranziciji (1945.-1948.)“, u: Desničini susreti 2009. Zbornik radova (ur. Drago Roksandić; Magdalena Najbar-Agičić; Ivana Cvijović Javorina), Biblioteka Desničini susreti, sv. 4, Filozofski fakultet Sveučilišta u Zagrebu, Centar za komparativnohistorijske i interkulturne studije - FF press, Zagreb 2011., 163-176.

„Zagrebački Filozofski fakultet u revolucionarnoj tranziciji (1945.-1948.)", Prosvjeta. Novine za kulturu, 17/2010., br. 96, 41-42.

„...Pisac uvijek ima upravo onoliku slobodu stvaranja koliku sam sebi dozvoli..." Civilna kultura Vladana Desnice poslije 1945. godine, u: Desničini susreti 2010. Zbornik radova (ur. Drago Roksandić; Ivana Cvijović Javorina), Biblioteka Desničini susreti, sv. 5, Filozofski fakultet Sveučilišta u Zagrebu, Centar za komparativnohistorijske i interkulturne studije - Plejada, Zagreb 2011., 9-30.

„Srbi u Hrvatskoj (1989-1991): Između lojalnosti, neposlušlosti i pobune“, u: Neposlušnost (ur. Snježana Prijić-Samaržija; Petar Bojanić), Narodna biblioteka Srbije, Beograd 2011., 87-129.

"O manjinskom legitimitetu i legalitetu: Srbi u Hrvatskoj između lojalnosti, neposlušnosti i pobune 1989.-1990.", u: Iz hrvatske povijesti 20. stoljeća - Iz hrvaške zgodovine 20. stoletja (ur. Iskra Iveljić; Stjepan Matković; Žarko Lazarević), Inštitut za novejšo zgodovino, Ljubljana 2012., $147-174$. 
2012.

„Izlazak izvan zidina. 18. stoljeće“, u: Povijest grada Zagreba. Knjiga 1. Od prethistorije do 1918. (ur. Ivo Goldstein; Slavko Goldstein), Novi liber, Zagreb 2012., 200-251.

„Sava Mrkalj, zagrebački eminens, u: An den Anfängen der serbischen Philologie. Na počecima srpske filologije. "Salo debeloga jera libo azbukoprotres" von Sava Mrkalj (1810-2010). „Salo debeloga jera libo azbukoprotres“ Save Mrkalja (1810-2010) (ur. Gordana Ilić Marković; Anna Kretschmer; Miloš Okuka), Philologica Slavica Vindobonensia 1, Peter Lang, Frankfurt am Main 2012., 129-146.

"Sava Mrkalj, zagrebački eminens", Radovi Zavoda za hrvatsku povijest Filozofskog fakulteta Sveučilišta u Zagrebu, 43/2011., 221-234.

„Sava Mrkalj: zagrebački eminens“, Prosvjeta. Novine za kulturu, 18/2011., br. 102, 16-21.

„Prvi kongres kulturnih radnika Hrvatske (Topusko, 25.-27. lipnja 1944.): iskustvo i aproprijacije“, u: Intelektualci i rat 1939.-1947. Zbornik radova s međunarodnog skupa Desničini susreti 2011. (ur. Drago Roksandić; Ivana Cvijović Javorina), Biblioteka Desničini susreti, sv. 6, Filozofski fakultet Sveučilišta u Zagrebu, Centar za komparativnohistorijske i interkulturne studije - Plejada, Zagreb 2012., 97-118.

„L'Europe centrale existe-t-elle encore? Perspective d'une politique transnationale de coopération culturelle", Revue d'Allemagne, 44/2012., br. 2, 171-188. Francuski.

„Esiste ancor sempre l'Europa centrale?", Quaderni. Centro di Ricerche Storiche di Rovigno, 24/2013., 7-28. Talijanski.

„Postoji li još uvijek Srednja Europa?“, Historijski zbornik, 45/2012., br. 1, 187-201.

\section{3.}

"Matasovićevi inovacijski doprinosi vojnokrajiškoj historiografiji“, u: Josip Matasović i paradigma kulturne povijesti. Zbornik radova sa znanstvenoga skupa održanog u Slavonskom Brodu 23.-24. studenoga 2012. (ur. Suzana Leček), Hrvatski institut za povijest, Podružnica za povijest Slavonije, Srijema i Baranje - Hrvatski državni arhiv - Društvo za hrvatsku povjesnicu, Slavonski Brod - Zagreb 2013., 93-109.

„Zatvaranje kruga. Dr Uroš Desnica (Obrovac, 28. VIII 1874. - 13. VII 1941.)“, u: Spomenica dr Danice Milić (ur. Bojana Miljković-Katić), Istorijski institut Beograd: Zbornik radova, knj. 27, Istorijski institut, Beograd 2013., 295-314.

„Ratni dani Vladana Desnice“, u: Intelektualci i rat 1939.-1947. Zbornik radova s međunarodnog skupa Desničini susreti 2012., dio 2. (ur. Drago Roksandić; Ivana Cvijović Javorina), Biblioteka Desničini susreti, sv. 8, Filozofski fakultet Sveučilišta u Zagrebu, Centar za komparativnohistorijske i interkulturne studije - FF press, Zagreb 2013., 529-555.

"Gli anni di guerra di Vladan Desnica (1938 - 1949)", Quaderni. Centro di Ricerche Storiche di Rovigno, 25/2014., 141-175. Talijanski.

„Historijski revizionizam i/li južnoslavenska historiografija poslije raspada Jugoslavije“, u: Politička upotreba prošlosti. O istorijskom revizionizmu na postjugoslavenskom prostoru (ur. Momir Samardžić; Milivoj Bešlin; Srđan Milošević), Alternativna kulturna organizacija - AKO, Novi Sad 2013., 27-32. 


\section{4.}

„Ličko-krbavski Bunjevci u 'dugom' 18. stoljeću: od Vlaha katolika do Hrvata“, u: Bunjevci u vremenskom i prostornom kontekstu (ur. Milana Černelić; Jadranka Grbić Jakopović; Marijeta Rajković Iveta; Tihana Rubić; Matija Dronjić; Mihovil Gotal), Filozofski fakultet Sveučilišta u Zagrebu, Odsjek za etnologiju i kulturnu antropologiju - Zavod za kulturu vojvođanskih Hrvata, Subotica - FF press, Zagreb 2014., 31-44.

„Međunarodni sveučilišni centar u Islamu Grčkom i mediteranska akademska zajednica: razvoj i perspektive", u: Kula Jankovića. Spomenik kulture - pokretač održivog razvoja Ravnih kotara. Baština, interkulturalizam i revitalizacija. Zbornik radova (ur. Drago Roksandić; Marijeta Rajković Iveta; Tihana Rubić), Biblioteka Desničini susreti, sv. 9, Filozofski fakultet Sveučilišta u Zagrebu, Centar za komparativnohistorijske i interkulturne studije - Plejada, Zagreb 2014., 101-120.

„Vladan Desnica, intelektualac danas“, u: Intelektualac danas. Zbornik radova s međunarodnog skupa Desničini susreti 2013. (ur. Drago Roksandić; Ivana Cvijović Javorina), Biblioteka Desničini susreti, sv. 10, Filozofski fakultet Sveučilišta u Zagrebu, Centar za komparativnohistorijske i interkulturne studije - Plejada, Zagreb 2014., 197-209.

„Prosvijećena' modernizacija i tolerancija u Habsburškoj Monarhiji u 18. stoljeću: Problemi pristupa - konfliktni koncepti i kontradiktorne prakse“, u: Hrvati i Srbi u Habsburškoj Monarhiji u 18. stoljeću: interkulturni aspekti "prosvijećene“ modernizacije. Zbornik radova s Hrvatsko-srpskog znanstvenog kolokvija 2011. (ur. Drago Roksandić), Biblioteka Desničini susreti, sv. 11, Filozofski fakultet Sveučilišta u Zagrebu, Centar za komparativnohistorijske i interkulturne studije - FF press, Zagreb 2014., 35-44.

„Prosvijećena' modernizacija i tolerancija u Habsburškoj Monarhiji u 18. stoljeću: problemi pristupa - konfliktni koncepti i kontradiktorne prakse", Tabula: časopis Filozofskog fakulteta, Sveučilište Jurja Dobrile u Puli, 12/2014., 205-215.

„Dr. Uroš Desnica 1918. - 1919.: životopisne nedoumice na raskrižju epoha“, u: Spalatumqve dedit ortum. Zbornik povodom desete godišnjice Odsjeka za povijest Filozofskog fakulteta u Splitu (ur. Ivan Basić; Marko Rimac), Filozofski fakultet Sveučilišta u Splitu, Odsjek za povijest, Split 2014., 499-511.

\section{5.}

„Koncept višegraničja i osmanska baština na Triplex Confinium-u u ranome novom vijeku", Prilozi za orijentalnu filologiju, 64/2015., 441-451.

"I Morlacchi dalmati nella prima età moderna: eredità e identità da prospettive contrastanti“ (prevela Francesca Rolandi), u: Storia e identità storica nello spazio euromediterraneo (ur. Rosa Maria Delli Quadri), Collana Terra Murata - Incontri mediterranei, Guida Editori, Napoli 2015., 137-166. Talijanski.

„Vladan Desnica i Magazin Sjeverne Dalmacije: književnik i (ne)moć tradicije“, u: Vladan Desnica i Split 1920. - 1945. Zbornik radova sa znanstvenog skupa Desničini susreti 2014. (ur. Drago Roksandić; Ivana Cvijović Javorina), Biblioteka Desničini susreti, sv. 13, Filozofski fakultet Sveučilišta u Zagrebu, Centar za komparativnohistorijske i interkulturne studije - FF press, Zagreb 2015., 181-234. 
Drago Roksandić; Ivana CVIJOvić Javorina, "Splitske adrese Vladana Desnice“, u: Vladan Desnica i Split 1920. - 1945. Zbornik radova sa znanstvenog skupa Desničini susreti 2014. (ur. Drago Roksandić; Ivana Cvijović Javorina), Biblioteka Desničini susreti, sv. 13, Filozofski fakultet Sveučilišta u Zagrebu, Centar za komparativnohistorijske i interkulturne studije - FF press, Zagreb 2015., 361-365.

„Krležina Enciklopedija Jugoslavije između euroskepticizma i euronormativizma“, u: Europa i enciklopedija: kultura i kodifikacija. Zbornik radova (ur. Vlaho Bogišić), Pravni fakultet Sveučilišta u Zagrebu - Leksikografski zavod Miroslav Krleža, Zagreb 2015., 167-184. Vidjeti, također: „Krležina Enciklopedija Jugoslavije između euroskepticizma i euronormativizma: prilog poznavanju početaka Krležina projekta Enciklopedije Jugoslavije“, Studia lexicographica, 8/2014., br. 2 (15), 5-22.

Drago Roksandić; Nicolò SPONZA, „Triplex Confinium (tromeđa) kao višerječje. Ranonovovjekovni kartografski kontrasti“, Titius, 8/2015., 63-81.

Drago Roksandić; Nicolò SPonzA, "Il Triplex confinium come area fluviale plurima. Contrasti cartografici della prima età moderna“, Atti del Centro di Ricerche Storiche di Rovigno, 45/2015., 91-109. Talijanski.

„Antun Vujić između 'kulture sjećanja' i kritičke refleksije“, Književna republika, 14/2016., br. 5-8, 56-59.

Autori: Bruno Kragić; Goran Sunajko; Goran Tribuson; Drago Roksandić; Nikola PetKović; Tonči KURSAR; Biserka CvJetIČAnIN; Zvonko Maković; Milan F. ŽıvKović; Branko ČEGEC

\section{6.}

"Kud koje žure brzi kraci / a vode svi u bespuće'“: Vladan Desnica u Splitu od 1935. do 1941. godine", u: Split i Vladan Desnica i Split 1918. - 1945.: Umjetničko stvaralaštvo između kulture i politike. Zbornik radova sa znanstvenog skupa Desničini susreti 2015. (ur. Drago Roksandić; Ivana Cvijović Javorina), Biblioteka Desničini susreti, sv. 14, Filozofski fakultet Sveučilišta u Zagrebu, Centar za komparativnohistorijske i interkulturne studije - FF press, Zagreb 2016., 415-458.

Drago RoKSANDIĆ; Ivana CVIJOVIĆ JAVORINA, „Profesori Filosofičko-historičkog odjela Mudroslovnog fakulteta Sveučilišta Franje Josipa I. u Prvom svjetskom ratu“, u: V. kongres hrvatskih povjesničara. Krize, sukobi i solidarnost u povijesnoj perspektivi. Zbornik sažetaka (ur. Damir Agičić; Tomislav Galović; Željko Holjevac), Hrvatski nacionalni odbor za povijesne znanosti - Društvo za hrvatsku povjesnicu - Odjel za povijest Sveučilišta u Zadru, Zagreb 2016., 163 (sažetak)

\section{7.}

„Das 'Triplex Confinium' und die kroatische Militärgrenze im 18. Jahrhundert auf Karten für den öffentlichen Gebrauch“, u: Die Türkenkriege des 18. Jahrhundertd. Wahrnehmen - Wissen - Erinnern (ur. Wolfgang Zimmermann; Josef Wolf), Landesarchiv Baden Württemberg - Institut für donauschwäbische Geschichte und Landeskunde, Schnell \& Steiner 2017., 219-234.

„Zapovidi Babogredske kompanije 1823. - 1824. Povodom kritičkog izdanja“, u: Zapovidi Babogredske kompanije 1823. - 1824. (ur. Drago Roksandić; Luka Jakopčić), Filozofski fakultet Sveučilišta u Zagrebu, Centar za komparativnohistorijske i interkulturne 
studije - Institut za književnost i umetnost u Beogradu - FF press, Zagreb - Babina Greda - Županja 2017., IX-XVIII.

"Jugoslavenstvo prije Jugoslavije", u: Jugoslavija u istorijskoj perspektivi (ur. Latinka Perović; Drago Roksandić; Mitja Velikonja; Wolfgang Höpken; Florian Bieber), Helsinški odbor za ljudska prava u Srbiji, Beograd 2017., 27-54.

„Yugoslavism before the creation of Yugoslavia“", u: Yugoslavia from a Historical Perspective (ur. Latinka Perović; Drago Roksandić; Mitja Velikonja; Wolfgang Höpken; Florian Bieber), Helsinki Committee for Human Rights in Serbia, Belgrade 2017., 29-61. Engleski.

„Vladan Desnica i Istorija kotarskih uskoka Vladana Desnice", u: Hrvatsko-srpski/srpsko-hrvatski interkulturalizam danas. Zbornik radova s međunarodnog znanstvenog skupa Desničini susreti 2016. (ur. Drago Roksandić), Biblioteka Desničini susreti, sv. 15, Filozofski fakultet Sveučilišta u Zagrebu, Centar za komparativnohistorijske i interkulturne studije - Institut za književnost i umetnost u Beogradu - FF press, Zagreb 2017., 283-296.

„Nezavisna Država Hrvatska u kotarevima Glina i Vrginmost (travanj 1941. - siječanj 1942.): Prostorne i vremenske logike nasilja", u: Nečakov zbornik. Procesi, teme in dogodki iz 19. i 20. stoletja (ur. Kornelija Ajlec; Bojan Balkovec; Božo Repe), Historia 25, Znanstvena zbirka Oddelka za zgodovino Filozofske fakultete Univerze v Ljubljani, Znanstvena založba Filozofske fakultete Univerze v Ljubljani, Ljubljana 2018., 271-307.

\section{8.}

"Gerasim Zelić - Homo Mediterraneus", Prosvjeta. Novine za kulturu, 142/2018., 22-25. "The First World War: A History of Hatred in South East Europe“, u: Postimperiale Narrative im zentraleuropäischen Raum (ur. Marijan Bobinac; Johanna Chovanec; Wolfgang Müller-Funk; Jelena Spreicer), Narr Francke Attempto Verlag GmbH + Co. KG, Tübingen 2018., 143-152. Engleski.

"O događaju i 'dugim trajanjima': 1918. u mnogostrukim perspektivama“/ "On the Event and 'Longue Durée': 1918 in Multiple Perspectives" (prijevod na engleski Tomislav Branđolica), Radovi Zavoda za hrvatsku povijest, 50/2018., br. 1 (2018), 11-23 i 24-35. Hrvatski i engleski.

Drago Roksandić i Šime Pilić, „Sibe Miličić na konferenciji kulturnih radnika Dalmacije (Hvar, 18. i 19. prosinca 1943.)“, u: Josip Sibe Miličić: vreme, prostor, sudbine. Međunarodni interdisciplinarni zbornik radova (ur. Svetlana Šeatović; Sanja Roić), Institut za književnost i umetnost - Univerzitetska biblioteka "Svetozar Marković“ - Centar za komparativnohistorijske i interkulturne studije Filozofskog fakulteta Sveučilišta u Zagrebu, Beograd 2018., 35-70.

\section{9.}

„Spatial and temporal logics of violence. The Independent State of Croatia in the districts of Glina and Vrginmost (April 1941-January 1942)“, u: Mass Violence in Modern History: Local Dimensions of the Second World War in Southeastern Europe (ur. Xavier Bougarel; Hannes Grandits; Marija Vulesica), Routledge, Abingdon, UK - New York 2019., 106-140. Engleski. 
„Iracionalizacije racionalnog ili racionalizacije iracionalnog - zagrebačke mržnje 1902. godine", u: Što sanjamo. Knjiga radova povodom 70. rođendana profesora Dušana Marinkovića (ur. Dubravka Bogutovac; Virna Karlić; Sanja Šakić), FF press - VSNM ZG, Zagreb 2019., 226-235.

"The Annales School, EHESS, and École de Paris: Memories of an étudiant libre in 1980/1981", u: Annales in Perspective: Designs and Accomplishments, vol. 1 (ur. Drago Roksandić; Filip Šimetin Šegvić; Nikolina Šimetin Šegvić), Centar za komparativnohistorijske i interkulturne studije - FF press, Filozofski fakultet Sveučilišta u Zagrebu 2019., 443-450. Engleski.

"Die südslawischen Walachen zwischen Kaiser und Sultan im 16. und 17. Jahrhundert", u: Kaiser und Sultan - Nachbarn in Europas Mitte, 1600 - 1700, Große Ausstellung, Badisches Landesmuseum, 2019./2020. Njemački. (u tisku)

\section{UREDNIČKI, REDAKTORSKI I RECENZENTSKI RADOVI}

1979.

„Rasprava o prelazu iz feudalizma u kapitalizam“, Marksizam u svetu, 2/1979., V-XIX + 1-188.

Drago RoKsandić (ur.)

„Rasprava o prijelazu iz feudalizma u kapitalizam“; „Bilješke uz izbor priloga“ (V-XIX); Paul SwEEzY, „Kritika“ (1-26); Maurice DoвB, „Odgovor“ (27-38); Kohachiro TAKaHASH, „Prilog diskusiji“ (39-71); Giuliano ProCACCl; „Pregled rasprave“ (72-87); Eric HobsBawm, „Prijelaz iz kapitalizma u socijalizam“ (86-94); Robert BRENNER, „Izvori kapitalističkog razvoja: kritika neosmitovskog marksizma“" (95-111); Martin MURRAY, "Novi pogledi na prijelaz iz feudalizma u kapitalizam“ (112-142); Albert Soвoul, „Od feudalizma do kapitalizma. Francuska revolucija i problematika puteva prelaska“ (143-163); Ernesto LACLAU, „Feudalizam i kapitalizam u Latinskoj Americi“ (164-188)

\section{2.}

„Historiografija i Vojna krajina“, Naše teme, 26/1982., br. 11, 1886-1926.

Drago RoKSANDIĆ (ur.)

Autori: Mirjana Gross; Dragutin Pavlčević; Nikša Stančić; Mirko Valentić; Drago Roksandić

\section{3.}

„Pitanja marksističke istoriografije“, Marksizam u svetu, 12/1983., I-XII + 1-221.

Drago Roksandić, "Marksizam i suvremena historiografija“ (V-XI); Eric J. HobsBawM, "Doprinos Karla Marxa istoriografiji“ (1-19); Pierre VILAR, „Za bolje razumevanje između ekonomista i istoričara“ (20-38); Hans-Ulrich WEHLER, „Povijest kao historijska nauka o društvu“ (39-66); Guy BoIs, „Marksizam i nova historija“ (67-87); Keith NIELD, „Simptomatičan spor? Beleške o odnosu između marksističke teorije i istorijske prakse u Britaniji““ (88-111); György Ránkı, „Beleške o istoriji društva“ (112-146); Luciano GruPPI, „O 'marksisitičkom istoricizmu'“ (147-165); Rosario VILLARI, „Mesto istorije“ (166-170); Miroslav HROCH, „Buržoaske revolucije u Evropi“ (171-221) 


\section{4.}

"Marksističko shvatanje istorije“, Marksizam u svetu, 1/1984., 1-261.

Drago RoksAndić, "O ovom izboru“ (5-10); Helmut FleISCHER, "Totalitet povijesnog procesa“ (11-54); Michel HenRY, "Redukcija totaliteta“ (55-111); Jürgen HaBERMAS, "O subjektu povijesti“ (120-170); Maurice GodelIER, „Prelazak iz jednog načina proizvodnje u drugi“ (171-215); Jerzy TOPOLSKI (235-261)

"Južnoslavenski narodi u prijelazu iz feudalnog u građansko društvo. Uvodne napomene", Naše teme, 28/1984., br. 4-5, 653-654.

Igor Karaman, „Prijelaz ili modernizacija. Društvenohistorijski procesi modernizacije i problemi prijelaznih razdoblja“ (Naše teme, 28/1984., br. 4-5, 655-676); Nikša Stančıć, "Od naroda k naciji. Prijelaz iz feudalizma u kapitalizam, nacija i Hrvatski narodni preporod“ (Naše teme, 28/1984., br. 4-5, 677-697); Milorad Pavić, "Stil i stalež“ (Naše teme, 28/1984., br. 4-5, 698-706); Branislav ĐuRĐEv, "Protiv shematike prijelaza. Napomene o razvitku građanskog društva u povijesti južnoslavenskih naroda“ (Naše teme, 28/1984., br. 4-5, 707-712); Mirjana Gross, „Zemljišno rasterećenje u civilnoj Hrvatskoj i Slavoniji“ (Naše teme, 28/1984., br. 11, 2397-2408); Dragutin PAVLIČEvić (Naše teme, 28/1984., br. 11, 2409-2424); Igor KARAMAN, „Tranzicija stanovništva u povijesnim tokovima modernizacije društva" (Naše teme, 30/1986., br. 12, 2033-2062)

„Dokumenti - Sava Mrkalj“, Književnost, 4-5/1984., 502-591.

Sava Mrkals, "Oda” (502-503); Jovan Deretić, "Sava Mrkalj kao jezički mislilac” (504-507); Pavle Ivıć, "O mestu Save Mrkalja u istoriji srpske kulture“ (508-512); Mitar PEŠIKAN, „Mrkaljeva reformatorska zamisao u svetlu ukupnog razvoja našeg pisma“ (513-519); Drago RoKSANDIĆ, „O Srbima u hrvatskim zemljama u Mrkaljevo doba“ (520-534); Vojin Matić, „Kobna obdarenost“ (525-545); Dušan Jovıć, "Lingvistička analiza pesmarice Save Mrkalja“ (546-552); Milorad PAVIĆ, „Stilska pozicija Save Mrkalja“ (553-556); Amfilohije Radović, "Religiozni lik Save Mrkalja“ (557-571); Aleksandar MLadenović, „"Palinodija' Save Mrkalja“ (572-586); Gojko NıKolı̌s, „Nešto o Savi i povodom..." (587-591)

Napomena: Ovaj tematski broj Književnosti posvećen je Savi Mrkalju (1783. - 1833.) povodom 200. godišnjice rođenja i 150. godišnjice smrti. Inicijativu je stjecajem prilika istovremeno podržala nekolicina poznavatelja problematike s Mrkaljem u vezi pa ju je nemoguće vezati samo za jednu osobu. Presudne su bile podrške Gojka Nikoliša i Mitra Pešikana. Pjesmu „Oda“ pronašla je u Muzeju Srpske pravoslavne crkve u Beogradu kolegica Gordana Krivokapić i dala je Dragi Roksandiću, znajući za njegov interes za Mrkalja. Budući da Uredništvo Književnosti nije objavilo tko je pronašao ovu Mrkaljevu zagrebačku pjesmu iz 1805. godine, čini se to ovom prilikom.

\section{5.}

Okrugli stol s povodom: Dunja RIHTMAN-AuGušTIN, Struktura tradicijskog mišljenja, Školska knjiga, Zagreb 1984., 198 str. (Naše teme, 29/1985., br. 4-6, 385-390)

Sudjelovali: Ivan SAlEčić, "Slovo razlike“ (379-384); Drago RoKSANDić, „Povijesno mišljenje između antropologije i socijalne historije“ (385-390); Dragutin PAVLIČEVIĆ, "Kućne zadruge ili struktura tradicijskog mišljenja“ (391-395); Zorica STIPETı́, „Kroz prizmu seljačke ideologije“ (396-399); Branka BoBan, „Pogledi Antuna Radića na kućne zadruge“ (400-403); Zvonko Lerotić, "Patrijarhalno ustrojstvo zadruga i grupno vlasništvo“ (404-409); Zorica RAJKović, "Tradicija i razumijevanje suvremenosti“ (410-411); Lydia SkLEVICKY, "Tradicija i društveni položaj žene“ (412-415); Nikša STANČıć, "Unapređivanje metoda društvenih znanosti“ (416-420); Ivan LozıcA, "Nekoliko opaski o stvarnom i zamišljenom redu“ (421-422); Dunja RıHTMAn-AuguŠtıN, „Kritička refleksija etnologije“ (423-426)

Drago Roksandić; Đorđe Stanković; Zorica Stipetıć, „Velikosrpski hegemonizam i drugi nacionalizmi u protivrečnostima jugoslovenskog društva 1918-1941 (teze) “, Naše teme, 29/1985., br. 7-9, 878-885.

„Poziv na istraživačku anketu“, Naše teme, 29/1985., br. 7-9, 877. 
„Balkanska društva na početku veka. Uzroci i posledice balkanskih ratova“, Marksistička misao, 4/1985., 119-177.

„Uvodna napomena“ (119)

Izbor prioćenja s međunarodnoga znanstvenog skupa Centralno-istočna Evropa u doba balkanskih ratova (Filozofski fakultet Univerziteta u Beogradu, Istorijski institut, Balkanološki institut SANU i Brooklyn College, NY, Beograd, 19. - 21. rujna 1985.): Stephen A. FISCher-Galati; Dimitrije Đordević; Milorad EкмĚ̌ić; Andrej Mıтrović.

\section{6.}

„Naša tema: Razgovor o knjizi: Antun Miletić, Koncentracioni logor Jasenovac 1941 - 1945. Dokumenta, I - II." (Naše teme, 30/1986., br. 9, 1265-1320)

Sudjelovali: Antun Miletić; Petar Strč́ć; Mihael Sobolevski; Jefto Šaš́̌́c; Anđelko Barbić; Đuro Zatezalo; Leo Kobsa; Milan Vukmanović; Ivan Jelćć; Nikola Žıvković; Drago Roksandić

Drago Roksandić; Dragutin Lalović (prir.), „Naša tema: Temeljni problemi povijesti Jugoslavije“, Naše teme, 30/1986., br. 12, 1907-2032.

Sudjelovali: Gordana Vlafčćć; Drago Roksandić; Dragutin Lalović; Branko Petranović; Dušan Bilandžlć; Đorđe Stanković; Janko Prunk; Mirjana Gross; Janko Pleterski; Momčilo Zečević; Mile BJELAAAC; BOSiljka JANAATOVIĆ

„Socijalna historija o ideologiji, državi i naciji“, Naše teme, 30/1986., br. 12, 2063-2064. Izbor tekstova: Georges DuBy, „Socijalna historija i društvene ideologije“ (prevela s francuskog Mirjana Paić) (2065-2078); „Historičar danas. Razgovor s Georgeom Dubyjem“ (prevela s francuskog Mirjana Paić) (2079-2084); Pierre VILAR, „Država i nacija u svesti Španaca: sadašnjost i istorija“ (preveo sa španjolskog Nenad Fejić) (2085-2100)

Istoriografija, marksizam i obrazovanje. Nedjelja marksističkih rasprava '85 (ur. Milenko Marković; Vukašin Stambolić; Drago Roksandić), Izdavački centar Komunist, Beograd 1986., I-VI + 1-298.

Milenko Marković; Vukašin Stambolić; Drago Roksandić (ur.)

Stručni i znanstveni prilozi s Nedelje marksističkih rasprava 1985, održane u Neumu od 4. do 8. veljače 1985., s „Predgovorom“ Uređivačkog odbora (V-VI) i stručnim ili znanstvenim prilozima Hotimira Burgera, Branka Petranovića, Đorđa Stankovića, Čedomira Popova, Nikše Stančlća, Janka Pleterskog, Miroslava R. Đorbevića, Envera Redžlća, Vase Milinčevića, Nikole Činge, Drage Roksandića, Mirjane Gross, Zorice Stipetić, Hrvoja Matrovića, Milutina Perovića, Ignacija Vojea, Ivana Obradoví́A, Marijana Maticke, Stanislava Stojanovića i Vasilija Krestí́A (1-298).

\section{8.}

Drago Roksandić; Mira Kolar-Dimitrijević (ur.), Glina. Glinski kraj kroz stoljeća (1284-19441984), Skupština općine Glina - Institut za historiju radničkog pokreta Hrvatske u Zagrebu - Filozofski fakultet Sveučilišta u Zagrebu, Zavod za hrvatsku povijest, Glina 1988., 624 str.

Mira Kolar-Dimitruević; Drago Roksandić, „Predgovor“ (3); „Kazalo osobnih imena“ (604-613); „Kazalo geografskih pojmova“ (614-619)

\section{9.}

Drago Roksandić; Petar Strpić (ur.), „Naša tema: Mediteran“, Naše teme, 33/1989., br. 5, 979-1095. 
Fernand BraudeL, „Uloga sredine“ (preveo s francuskog Željko Klaić) (979-1037); Thierry PAQUOT, „Poziv na povijest“ (preveo s francuskog Željko Klaić) (1038-1040); Immanuel WalLerSTEIN, „Braudel - čovjek okolnosti“ (preveo s francuskog Željko Klaić) (1041-1052); Alberto TeNENTI, „Domene dugog trajanja kod Fernanda Braudela“ (prevela s talijanskog Mica Desnica) (1053-1060)

„Okrugli stol: Mediteran“: Fernand Braudel, Christine Ockrent, Jean Guilaine, Mirko Dražen Grmek, Hélène Ahrweller, Robert Mantran, Maurice Aymard, Alain Guillerm, André Nouschi, Vitorino Magelhăes GodinHo, Alain Denis (preveo s francuskog Željko Klaić) (1061-1095)

Vidjeti: Damir AGıčlć, „Mediteran“, Časopis za suvremenu povijest, 21/1989., br. 1-3, 225-230.

„U povodu dijaloga u hrvatskoj historiografiji“, Naše teme, 33/1989., br. 7-8, 1864-1866. „Naša tema: Počeci moderne Hrvatske“, Naše teme, 33/1989., br. 7-8, 1864-1954. Mirjana Gross, Počeci moderne Hrvatske: neoapsolutizam u civilnoj Hrvatskoj i Slavoniji 1850. 1860., Centar za povijesne znanosti Sveučilišta u Zagrebu, Odjel za hrvatsku povijest - Globus, Zagreb 1985., 521 str.

Prilozi u raspravi: Dragutin PAvıIČEVIĆ, „Drugačije o neoapsolutizmu u Hrvatskoj“ (1867-1870); Hodimir SIROTKOvić, „Pravo i modernizacija“ (1871-1875); Agneza SzabO, „Prema socijalnoj historiji“ (1876-1879); Mile BJelAJAC, "Klasna borba' ili kriminal“ (1880); Mirjana Gross, „Kako pisati ‘historiju društva'?" (1881-1884)

Iso KRŠNJAvı, Zapisci: iza kulisa hrvatske politike, sv. 1-2 (prir. Ivan Krtalić), Mladost, Zagreb 1986., 442 str. + 451-908.

Mirjana Gross, „O političkoj uvjetovanosti djelovanja Ise Kršnjavog“ (1885-1887); Petar STRČı́́, „Sporna kritičnost izdanja 'Zapisaka'“ (1888-1890); Miroslav Šıcel, „O estetskom sustavu I. Kršnjavog“ (1891-1892); Mira Kolar-DimıtRIJEVIĆ, „I. Kršnjavi u modernizaciji Hrvatske“ (1893-1895); Željka ČORAK, „I. Kršnjavi i hrvatsko društvo njegova doba“ (1896-1897); Olga MARUšEVSKI, „U povodu 'Zapisaka' I. Kršnjavoga“" (1898-1901)

Petar Korunić, Jugoslavenska ideologija u hrvatskoj i slovenskoj politici. Hrvatsko-slovenski politički odnosi 1840 - 1870., Centar za povijesne znanosti Sveučilišta u Zagrebu, Odjel za hrvatsku povijest - Globus, Zagreb 1986., 419 str.

Janez Roter, „Povijesni kontinuitet slovensko-hrvatskih odnosa“ (1902-1904); Dragutin PAVLIČEVIĆ, "Napomene o hrvatsko-slovenskim odnosima“ (1905-1907); Predrag MATVEjević, „Terminološke i druge nedoumice" (1908-1911)

Drago Roksandić, Vojna Hrvatska - La Croatie militaire. Krajiško društvo u Francuskom Carstvu (1809-1813), sv. 1-2, Biblioteka Povijesna istraživanja, Školska knjiga - Stvarnost, Zagreb 1988., $360+282$ str.

Igor KARAMAN, "Društvo, mit i iskustvo“ (1912-1916); Miroslav BerToŠA, "Jedan metodološki obrazac socijalne historije“ (1917-1920); Dragutin PAVLIČEVIĆ, "O krajiškom agrarnom društvu“ (1921-1924); Galib ŠLıvo, „Bosansko-hrvatski krajiški konflikti“ (1925-1929); Ivo PERIĆ, „Dvojica dubrovačkih jezikoslovaca“ (1930-1934); Agneza SzABO, "Socijalna historija Vojne krajine" (1935-1937); Zvonko Kovač, "Regionalizmi i nacionalne integracije“ (1938-1941); Fedor MOAČANIN, „Refeudalizacija Vojne krajine?“ (1942-1943); Ivan JURIšlć, „Krajiško školstvo i društveno raslojavanje“ (1944); Mirjana Gross, „Regionalna historija i historija društva“ (1945-1947); Nevio ŠEtí́, „Vojna Hrvatska i Istra (1809-1813)“ (1948-1949); Frano BARAS, „Tragom majora Matutinovića" (1950-1952); Igor Karaman, "Sporno ilirstvo“ (1953-1954)

„Naša tema: Modeli razvoja i teorije modernizacije u Istočnoj Evropi između dva svjetska rata", Naše teme, 33/1989., br. 10, 2465-2581.

Keith HITCHINS, „Rumunjski taranizam - 'treći put'“ (2465-2483); Andrew C. JANOS, „Politika zaostalosti u kontinentalnoj Evropi 1780-1945“ (2484-2511); Andrzej WALICKI, "Razvoj i modernizacija u podijeljenoj Poljskoj“ (2512-2551); Ivan SzELÉNYI, „Ideje o 'trećem putu' u Mađarskoj“ (2552-2566); Virgil Nemolanu, „Rumunjski razvojni modeli 1940-ih godina. Lovinescu, Blaga i slučaj 'Cercul Literatura'“ (2567-2581) 
„Razgovor o knjizi: O. Utješenović Ostrožinski, Kućne zadruge - Vojna krajina; Karl Marx, Utješenović, Biblioteka Povijesna istraživanja, Školska knjiga - Stvarnost, Zagreb 1988., 280 str.

Igor KARAMAN, „Tradicionalne seoske institucije u procesima modernizacije“ (2635-2652); Dragutin PAVLIČEVIĆ, „Pokušaj tipizacije kućnih zadruga“ (2653-2659); Miomir JAKŠIĆ, „O odnosu naturalne i robne proizvodnje. Zadruge kao jedinice proizvodnje i potrošnje“ (2660-2671); Latinka PEROvić, „Patrijarhalne zajednice kao temelj preobražaja društva“ (2672-2677); Vlado Pulız, „Modernizacija razara kućne zadruge" (2678-2682); Dunja RıHTMAN-AuGuštıN, "O slugama u zadruzi ili o jednom previdu“ (2683-2688); Petar KorUnić, "Procesi modernizacije u djelu O. U. Ostrožinskog. Prilog studiji o političkoj ideologiji“ (2689-2695)

\section{0.}

A. J. P. TAYLOR, Habsburška Monarhija 1809-1918 (s engleskoga preveo Omer Lakomica), Znanje, Zagreb 1990., 372 str.

Drago Roksandić, „Aktualni Taylor“ (339-349)

Pierre VILAR, Zlato i novac u povijesti 1450 - 1920, Nolit, Beograd 1990., 452 str.

Drago Roksandić, „Umjesto pogovora“ (435-447)

Vidjeti: „Problemi izgradnje socijalne istorije (Sa Pjer Vilarom razgovara Drago Roksandić) (prevela s francuskog Jagoda Krivokapić)“, Marksistička misao, 2/1982., 189-210; Pjer VILAR, „Razmišljanja o osnovama nacionalnih struktura“ (prevela s francuskog Gordana Stojanović), Marksistička misao, 2/1982., 211-235.

\section{5.}

Gabrijela VIDAN; Drago RokSANDIĆ (izabrali i uredili), "Lujo Matutinović i njegovo doba“, Gordogan, 16/1995., br. 39-40, Zagreb 1995., 202 str.

Sadržaj: Gabrijela VIDAN; Drago RoKSAndić, „Predgovor“ (3-4); Cvijeta Pavlović; Ivona SAvić; Gabrijela VIDAN (5-15); Drago RoKSANDIĆ, „Lujo Matutinović (1765.-1844.). Istraživački izazovi životopisa jednoga napoznatog maršala“ (16-42); Ivona SAvić, "Lujo Matutinović i njegovo vrijeme. Kronološke korespondencije“ (43-86); „Fragmenti Matutinovićevih rukopisa“ (prevele Sandra Prlenda, Jagoda Milinković i Ivona Savić) (87-106); „Spomenspis zapovjednika bataljuna Matutinovića..." (prevela Vesna Pavković) (107-123);

„Francuska nova povijest" (124); André BURGuì RE, „Historijska antropologija“ (preveo Željko Klaić) (125-145); Philippe Arı̇s, „Povijest mentaliteta“ (prevela Roza Hrstić) (146-162); Michel Vovelle, „Ideologije i mentaliteti“ (prevela Marija Semenov) (163-171); Michel Foucault, „Rađanje klinike“ (prevela Sandra Prlenda) (172-178); Fernand BraudeL, „Venecija“ (prevele Lada Burić i Sanja Burić) (179-191); „Treba li spaliti Fernanda Braudela?“ (prevela Vesna Pavković) (192-202)

\section{7.}

Pavao RitTer Vıtezović, Oživljena Hrvatska (prevela i priredila Zrinka Blažević), Biblioteka Latina et Graeca, knj. 40, Latina et Graeca - Hrvatski institut za povijest - Filozofski fakultet Sveučilišta u Zagrebu, Zavod za hrvatsku povijest, Zagreb 1997., 176 str. Drago Roksandić, „Napomena. O jednome novom pristupu Vitezoviću“ (5-7) 
1998.

Drago RoKSANDıć; Maja Brkıjačıć (ur.), Alexis de Tocqueville o američkoj povijesti, Filozofski fakultet Sveučilišta u Zagrebu, Zavod za hrvatsku povijest - United States Information Service, Zagreb 1998., 236 str.

Drago Roksandić; Maja BRKLıAČı́́, „Alexis de Tocqueville u hrvatskoj kulturi“ (7-11)

Drago Roksandić (ur.), Microhistory of the Triplex Confinium. International Project Conference Papers (Budapest, March 21-22, 1997), Budapest 1998., 160 str. Engleski, njemački i talijanski.

Drago Roksandić, „Preface“ (5-6). Engleski.

\section{9.}

Drago RokSAndić; Nataša ŠtefaneC (ur.), Diplomska radionica 1 prof. dr. Drage Roksandića, Filozofski fakultet Sveučilišta u Zagrebu, Zavod za hrvatsku povijest, Zagreb 1999. 222 str.

Drago RoksANDIĆ, „Zašto tiskati diplomske radnje?“ (9-18)

Radovi: Meri KUNČı́ć, „Homo universalis u talijanskoj renesansi“ (21-66); Marko ŠARIĆ, „Društveni odnosi u sandžaku Lika-Krka u 16. i početkom 17. stoljeća“ (67-130); Nataša ŠTEFANEC „Povijesna obzorja promjene statusa umjetnika i umjetnosti u srednjozapadnoj Europi i Italiji u 16. stoljeću“ (131-178); Sanja ZuвAK, ,Između prosvjetiteljstva i romantizma. Strukture kulturalnosti hrvatskoga narodnog preporoda (1835. - 1848.)“ (179-221)

Vidjeti: Valentina Gulin ZRNić, u: Narodna umjetnost. Hrvatski časopis za etnologiju i folkloristiku, 37/2000., br. 2, 235-236.

"Triplex Confinium", Radovi Zavoda za hrvatsku povijest Filozofskog fakulteta Sveučilišta u Zagrebu, 32-33/1999. - 2000., 323-419.

Mirela SluKAN Altić, „Karte kao izvor za ekohistorijska istraživanja tromeđe. Uvod u istraživanje kartografskih izvora Triplex Confiniuma“ (323-332); Drago RokSANDIĆ, „Dinara kao ekohistorijski problem - ranonovovjekovni kartografski aspekti“ (333-343); Nenad MOAČANIN, "O problemima kartografske identifikacije obavijesti iz osmanskih popisa bosanskih krajišta“ (345-347); Borna Fuerst-BJeLĽs, „Toponimija i percepcija u prostoru Triplex Confiniuma: Morlakija“ (349-354); Anna Maria Gruenfelder, „Karte kao izvori za proučavanje senjskih uskoka“ (355-363); Ivan JURIšić, „Ekohistorija fortifikacijskih ambijenata u Karlovačkom generalatu početkom 18. stoljeća“ (365-369); Željko HolJEVAC, „Odnos narativnih i kartografskih izvora prema ekohistoriji Triplex Confiniuma“ (371-382); Nataša ŠTEFANEC, "Kartografske obavijesti o gradovima na širem prostoru Triplex Confiniuma (1550. - 1700.)“ (383-397); Sanja LAZANIN, „Kartografski i narativni izvori za Karlovački generalat u prvoj polovici 18. stoljeća“ (399-407); Dubravka MLINARIć. „Novovjekovne kartografske interpretacije prostora tromeđe na temelju izvora iz Zbirke Novak" (409-419)

\section{0.}

Drago Roksandić; Nataša Štefanec (ur.), Constructing Border Societies on the Triplex Confinium. International Project Conference Papers 2. "Plan and Practise, How to Construct a Border Society? The Triplex Confinium c. 1700-1750" (Graz, December 9-12, 1998), CEU History Department, Budapest 2000., 288 str. Engleski.

Drago Roksandić; Nataša ŠtefaneC, "Preface“ (11-12). Engleski.

Vidjeti: Miroslav BertošA, „'Triplex confinium' ili povijest tromeđe“, u: Istı, Istra, Jadran, Sredozemlje. Identiteti i imaginariji. Feljtoni, elzeviri, kolumne, Dubrovnik University Press - Durieux, Zagreb - Dubrovnik 2003., 419-421. 
2001.

J[ohn] M[orris] Roberts, Povijest Europe (prevele Neđeljka Batinović i Vida Kostrenčić Lukić), Biblioteka Povjesnica, AGM, Zagreb 2002., 712 str.

Drago RoKSANDIĆ (stručna redaktura prijevoda)

Drago Roksandić, „Povijest Europe i hrvatska historiografija“ (11-22)

\section{3.}

Drago Roksandić; Ivan Mimica; Nataša Štefanec; Vinka Glunčić-BuŽančić (ur.), Triplex Confinium (1500-1800): Ekohistorija. Zbornik radova s međunarodnog znanstvenog skupa održanog od 3. do 7. svibnja 2000. godine u Zadru, Biblioteka Knjiga Mediterana 28, Književni krug - Filozofski fakultet Sveučilišta u Zagrebu, Zavod za hrvatsku povijest, Split - Zagreb 2003., 450 str.

Drago Roksandić; Nataša Štefanec, „Predgovor“ (5-9)

Drago Roksandić; Marijan MatickA; Damir Agıčıć; Tvrtko Jakovina; Ivica Šute; Hrvoje Petrić (ur.), Zbornik Mire Kolar-Dimitrijević. Zbornik radova povodom 70. rođendana, Filozofski fakultet Sveučilišta u Zagrebu, Odsjek za povijest - FF press, Zagreb 2003., 572 str.

Okrugli stol „Opus profesorice Mirjane Gross u srednjoeuropskoj historiografiji: iskustva i pouke“, 21. studenoga 2003., Vijećnica Filozofskog fakulteta u Zagrebu, DVD + CD-ROM 1 i 2.

\section{4.}

„Interkulturalizam u nastavi povijesti“; "Interkulturalizam u školskoj praksi“, Povijest u nastavi, 2/2004., br. 2/4, 2004., 279-372.

Drago RoksAndić, „Uvodna riječ. Tema broja: Interkulturalizam u nastavi povijesti“ (279-280)

Paul Boppe, Vojna Hrvatska (1809-1813). Hrvatske pukovnije u Napoleonovoj Velikoj armiji (prevela s francuskog Sandra Prlenda), Ceres, Zagreb 2004., 292 str.

Drago RoKSANDIĆ, „Oduživanje povijesnog duga: povodom hrvatskog prijevoda Boppeove knjige“ $(5-17)$

\section{5.}

„Na kraju prvog broja: Čemu 'Eko-eko'?", Ekonomska i ekohistorija. Časopis za gospodarsku povijest i povijest okoliša / Economic- and Ecohistory. Journal for Economic History and Environmental History, 1/2005., br. 1, 147-149.

Drago Roksandić (član Uredništva; predsjednik Međunarodnoga uredničkog vijeća)

Dragan Damjanović, Saborna crkva Vavedenja Presvete Bogorodice u Plaškom. Povijest episkopalnog kompleksa, SKD Prosvjeta, Zagreb 2005., 260 str.

Drago RoKsanDić; Čedomir VišsıIĆ (ur.)

Drago Roksandić; Zvonko Maković (recenzenti)

Drago Roksandić, „Predgovor“ (7-8) 
2006.

Marijana MARINOvić; Drago RokSANDIĆ (ur.), Zavičajna povijest u interkulturalnom kontekstu. Prvi hrvatski simpozij o nastavi povijesti (Opatija, od 27. do 29. studenoga 2003.). Zbornik (ur. Marijana Marinović; Drago Roksandić), Filozofski fakultet Sveučilišta u Zagrebu, Odsjek za povijest - Zavod za školstvo Republike Hrvatske - Društvo za hrvatsku povjesnicu Rijeka - Povijesno društvo Rijeka - Povijesno društvo otoka Krka - FF press, Zagreb 2006., 256 str.

Drago RoksANDIĆ, "Zavičajna povijest i interkulturalizam: prvi put“ (12)

\section{7.}

Egidio Ivetić; Drago Roksandić (ur.), Tolerance and Intolerance on the Triplex Confinium: Approaching the "Other" on the Borderlands, Eastern Adriatic and Beyond 1500-1800, Università degli Studi di Padova, CLEUP, Padova 2007., 361 str.

Egidio Ivetić; Drago Roksandić, "Introduction“ (9-13)

\section{8.}

Marc Bıoch, Apologija historije ili zanat povjesničara (prevela s francuskog Jagoda Milinković), Srednja Europa, Zagreb 2008., 188 str.

Drago Roksandić; Zrinka BlAŽEVIĆ (recenzenti)

Drago Roksandić, „Treba li danas čitati Marca Blocha? Povodom hrvatskog prijevoda Apologije historije“ (173-185)

Tea MAYHew, Dalmatia between Ottoman and Venetian Rule. Contado di Zara 1645 - 1718, Interadria. Culture dell'Adriatico 6, Viella, Roma 2008., 394 str.

Drago Roksandić, „Preface“ (7-9); Egidio Ivetic, „Preface“ (11-12)

Josip Matker; Mladen Medved; Silvestar Mileta (ur.) u suradnji s prof. dr. sc. Dragom RoKSANDIĆEM, Ogledalo konfinija. Hrvatska povijest i "Drugi“ (1500 - 1800.): problemi pristupa i istraživanja. Studentska iskustva, Filozofski fakultet Sveučilišta u Zagrebu, Odsjek za povijest - FF press, Zagreb 2008., 98 str.

Drago Roksandić, "Predgovor" (7-9); Ivana BelJAK, „Interkulturalizam u nastavi povijesti“ (11-14); Tanja MARETIĆ, „Pojam regije u ranonovjekovlju, interkulturni pristupi i metode u proučavanju regija hrvatske povijesti“ (15-18); Krunoslav MARJANOvić, "Komparativni pristupi i metode u istraživanju problema regija hrvatskih zemalja u ranom novom vijeku“ (19-30); Mia MARUšić, "Regionalnost i interkulturalnost u ranom novom vijeku kao odrednice u proučavanju povijesti Dalmacije" (31-38); Josip MATKER, „Pojam 'regije' u ranom novom vijeku kroz komparativnohistorijske pristupe i metode“ (39-43); Mladen MeDved, „Regija u ranom novom vijeku: Dubrovnik i zaleđe u 16. st.“ (44-49); Mladen Medved, "Nužnost komparativne historije“ (50-53); Mladen Medved, "Interkulturni pristupi“ (54-56); Silvestar MiLETA, „Pojam regija u ranom novom vijeku“ (57-60); Silvestar MILETA, „KOmparativni i interkulturni pristupi i metode $u$ istraživanjima regija hrvatske povijesti (1500-1800.)" (61-67); Stipe Mцıкоті́́, "Regija u ranom novom vijeku: Dalmacija u XVI. stoljeću“ (68-71); Stipe MLıкотı́́, „Europske regije i hrvatska povijest (cca. 1500-1800.): interkulturni pristupi i metode" (72-75); Stipe МцІкотІ́́, "Europske regije i hrvatska povijest (cca. 1500-1800.): komprativnohistorijski pristupi i metode“ (76-78); Danijel ŠvRAKA, „Pojam regija u ranonovovjekovlju“ (79-80); Milan VUKELĹc, "Komparativnohistorijski pristupi i metode te pojam interkulturalizma“ (81-84) 
2009.

Lujo Matutinović, Ogled o Ilirskim provincijama i Crnoj Gori (prevela s francuskog Jagoda Milinković), Školska knjiga, Zagreb 2009., 290 str.

Drago RoKSANDIĆ; Gabrijela VIDAN (stručna redaktura prijevoda)

Drago RoksAndić (provjera prijepisa izvornika)

Drago RoKSANDIĆ, „Predgovor: Kako čitati Luju Matutinovića“ (7-79); „Comment lire Lujo Matutinović? Résumé“ (traduit par Ines Sabotič) (58-62); „Prilog. Kuzmanić, Ante. Spomeni iz moga dnevnika. Članak VI.“, Zadarski list, god. XII., br. 89, Zadar 1873., 1-2 („Podlistak“)

Drago Roksandić; Damir Acıčıć (ur.), Spomenica Josipa Adamčeka, Filozofski fakultet Sveučilišta u Zagrebu, Odsjek za povijest - FF press, Zagreb 2009., 566 str.

Drago Roksandić; Damir AGıčlć, „Riječ urednika“ (9-10)

"Okrugli stol „Sima Ćirković. Sinteza srpske povijesti kao izazov hrvatskoj i srpskoj historiografiji i kulturi“ (moderirao Drago Roksandić), Radovi Zavoda za hrvatsku povijest Filozofskog fakulteta Sveučilišta u Zagrebu, 47/2009., 433-476.

Drago RoksAndić, „Riječ poslije“ (433-434); Sima ĆIRKOvIĆ, „Pisana poruka sudionicima Okrugloga stola 'Srbi među europskim narodima'“ (434); Damir AGıčlć, "O knjizi 'Srbi među europskim narodima'“ (434-438); Mladen ANČíc, "Nevolje s nacionalnom poviješću“ (439-441); Ivo BANAC, „O knjizi Sime Ćirkovića 'Srbi među europskim narodima'“ (442); Neven BuDAK, "O najnovijem pregledu srpske povijesti“ (442-445); Radivoj RaDIĆ, "Uravnotežena povesnica Srba“ (445-449); Milan Rıstović, "Nekoliko marginalija o knjizi Sime M. Ćirkovića 'Srbi među europskim narodima'" (449-454); Drago RoKSANDIĆ, "'Teme, pristupi i problemi' hrvatsko-srpskih i srpsko-hrvatskih dijaloga“ (454-458); Nikola SAMARDžlć, "'Srbi među evropskim narodima' - preobražaji, nedoumice, identiteti“ (458-476)

2010.

Daniel Baric; Jacques Le Rider; Drago Roksandić (ur.), Memoire et historie en Europe centrale et orientale, Collection "Histoire", Presses universitaires de Rennes, Rennes 2010., 360 str.

Daniel Baric; Jacques Le Rider; Drago Roksandić, „Préface“ (9-14)

Paul Kussan, Kratka povijest Treće ogulinske narodne graničarske pješadijske regimente. Prema sabranim spisima i poveljama Paula Kussana, upravnog kapetana (prevela Sonja Perković), SKD Prosvjeta, Zagreb 2010., 190 str.

Čedomir VIŠnıIĆ; Drago Roksandić (ur.)

Sanja LAZANIN; Drago RoksANDIĆ (stručna redaktura prijevoda)

Drago Roksandić, „Paul Kussan: Pitanja povodom izlaska iz anonimnosti“ (6-24)

"Na kraju jednog novog početka (Povodom 'Razgovora o Analima')", Pro tempore. Časopis studenata povijesti, 8/9/2010. - 2011., 270-273.

\section{1.}

"Ekohistorija Drave. Topics: Environmental History of the Drava River", Ekonomska i ekohistorija. Časopis za gospodarsku povijest i povijest okoliša / Economic- and Ecohistory. Journal for Economic History and Environmental History, 7/2011., br. 7, 5-128. Hrvoje Petrić; Drago Roksandić (ur.), „Novi pristupi starim temama“ (5-6)

Dragutin Feletar; Hrvoje Petrić; Drago Roksandić (ur.), Ekohistorija rijeke Drave. Zbornik s međunarodnog znanstvenog skupa (ur. Dragutin Feletar; Hrvoje Petrić; Drago Rok- 
sandić), Povijesno društvo Koprivnica - Društvo za hrvatsku ekonomsku povijest i ekohistoriju, Koprivnica 2011., 102 str.

Dragutin FeletaR; Hrvoje Petrić; Drago Roksandić, „Predgovor. Ekohistorija Drave: novi pristupi starim temama. Drava River Environmental History: New Approach to Old Problems" (5-8)

Drago Roksandić; Željko Holjevac (ur.), Radni listići. Sveščić 1. „Velike teme" moderne $i$ suvremene hrvatske povijesti (Doktorandska anketa), Filozofski fakultet Sveučilišta u Zagrebu, Odsjek za povijest, Poslijediplomski doktorski studij „Moderna i suvremena hrvatska povijest u europskom i svjetskom kontekstu“ - FF press, Zagreb 2011., 50 str.

\section{2.}

Drago Roksandić; Željko Holjevac (ur.), Radni listići. Sveščić 2. "Velike teme" moderne i suvremene hrvatske povijesti II. (Doktorandska anketa), Filozofski fakultet Sveučilišta u Zagrebu, Odsjek za povijest, Poslijediplomski doktorski studij „Moderna i suvremena hrvatska povijest u europskom i svjetskom kontekstu“ - FF press, Zagreb 2012., 78 str.

Drago RoKsAnDić (ur.), „Znanstveni kolokvij Kako poučavati o izgradnji Europe u vrijeme integracije zemalja europskog Jugoistoka?, Povijest u nastavi, 10/2012., br. 2 (20), 125-182.

Drago Roksandić, „Predgovor“ (127-128)

Dominique Borne (133-137); Étienne Françols (139-149); Peter Geiss (151-171); Gabrielle Grosse (173-177)

Drago RoKSANDiĆ; Branimir Janković (ur.), Baltazar Bogišić i njegovo doba u intelektualnohistorijskoj perspektivi, Filozofski fakultet Sveučilišta u Zagrebu, Odsjek za povijest, Poslijediplomski doktorski studij „Moderna i suvremena hrvatska povijest u europskom i svjetskom kontekstu“ - FF press, Zagreb 2012., 268 str.

Drago RoKSANDIć; Branimir JANKOVIĆ, "Urednički predgovor" (7-11)

Drago Roksandić, „Prilozi“ (239-245, 260-261)

Hannes Grandits, Obitelj i socijalne promjene u hrvatskim selima (18. - 20. stoljeće). Studije slučaja Bobovac i Lekenik (prevela Barbara Dukić) (ur. Drago Roksandić; Marijeta Rajković Iveta), Biblioteka Desničini susreti, sv. 7, Filozofski fakultet Sveučilišta u Zagrebu, Centar za komparativnohistorijske i interkulturne studije, Odsjek za etnologiju i kulturnu antropologiju - FF press, Zagreb 2012., 292 str.

Drago RoKSANDIĆ; Marijeta RAJKOvić IVETA, „Hannes Grandits u hrvatskoj historiografiji i antropologiji. Urednički predgovor" (7-11)

\section{4.}

Kristina MıLKović ŠARIĆ, Josip Jelačić u Prvoj banskoj pukovniji (1841. - 1848.). Prilozi za povijest političke ideologije Josipa Jelačića, Plejada, Zagreb 2014., 198 str.

Drago Roksandić (recenzent)

\section{6.}

Damir Acičić; Drago Roksandić; Tvrtko Jakovina (ur.), Spomenica Renea Lovrenčića, Filozofski fakultet Sveučilišta u Zagrebu - FF press, Zagreb 2016., 348 str.

Damir AGičlć; Drago RoKsandić; Tvrtko Jakovina, „Predgovor" (9-10) 


\section{7.}

Drago RokSANDić; Luka JakOPČı́ (ur.), Zapovidi Babogredske kompanije 1823.-1824. godine, Filozofski fakultet Sveučilišta u Zagrebu, Centar za komparativnohistorijske i interkulturne studije - Institut za književnost i umetnost u Beogradu - FF press, Zagreb - Babina Greda - Županja 2017., 194 str.

Drago Roksandić; Luka Jakopčić, „Babogredske Zapovidi 1829-ih i danas. Predgovor“ (VII-VIII) "Jugoslavija iz različitih uglova. Predgovor", u: Jugoslavija u istorijskoj perspektivi (ur. Latinka Perović; Drago Roksandić; Mitja Velikonja; Wolfgang Höpken; Florian Bieber), Helsinški odbor za ljudska prava u Srbiji, Beograd 2017., 12-14.

"Yu-History: A Multiperspective Historical Account. Foreword“, u: Yugoslavia from a Historical Perspective (ur. Latinka Perović; Drago Roksandić; Mitja Velikonja; Wolfgang Höpken; Florian Bieber), Helsinki Committee for Human Rights in Serbia, Belgrade 2017., 13-15. Engleski.

Maksimilijan VRHOVAC, Dnevnik / Diarium, sv. 2 (1810-1815.) (latinski tekst preveli na hrvatski i bilješkama popratili Metoda Hrg i Josip Kolanović), Croatica Christiana Fontes 29, Kršćanska sadašnjost - Filozofski fakultet Sveučilišta u Zagrebu, Zavod za hrvatsku povijest, Zagreb 2017., 908 str.

Drago Roksandić; Danijel Patafta (recenzenti)

Drago Roksandić, „Riječ unaprijed. Vrhovčev Diarium sv. 2“ (V-XII)

\section{8.}

Svetozar Borojević, Kroz Bosnu. Ilustrirani vodič C.-k. bosanske željeznice i Bosanskohercegovačke državne željeznice Doboj - Simin Han, Srednja Europa - Udruženje za modernu historiju, Zagreb - Sarajevo 2018., 108 str.

Drago Roksandić, „Kroz Bosnu ili željeznicom prema sreći“ (III-XI)

„Poticaj za objavljivanje prijevoda knjige dao je prof. dr. Drago Roksandić." (impressum)

\section{9.}

Annales in Perspective: Designs and Accomplishments, vol. 1 (ur. Drago Roksandić; Filip Šimetin Šegvić; Nikolina Šimetin Šegvić), Centar za komparativnohistorijske i interkulturne studije - FF press, Filozofski fakultet Sveučilišta u Zagrebu 2019., 466 str. Engleski. Drago Roksandić; Filip ŠIMEtIN ŠEGVIĆ; Nikolina ŠImEtin ŠEGVIĆ, "Mapping the Annales network" $(9-11)$

\section{(Su)urednik Biblioteke Povijesna istraživanja \\ (Blagota DRAŠKović; Drago RoKSANdić) (IRO Školska knjiga - NIRO Stvarnost, Zagreb)}

\section{7.}

Ljubo BoBan, Kontroverze iz povijesti Jugoslavije. Dokumentima i polemikom o temama iz novije povijesti Jugoslavije. Sv. I., Zagreb 1987., 456 str.

Eric Hobsbawm, Doba revolucije. Evropa 1789-1848., Zagreb 1987., 296 str. 
1988.

Drago Roksandić, Vojna Hrvatska - La Croatie militaire. Krajiško društvo u Francuskom Carstvu (1809-1813), sv. 1-2, Zagreb 1988., $360+282$ str.

Ognjeslav UtנešEnović OstrožInskı, Kućne zadruge - Vojna krajina; Karl Marx, Utješenović, Zagreb 1988., 280 str.

Drago RoKSANDIĆ (izbor tekstova i predgovor) (5-15)

\section{9.}

Ljubo BoBan, Kontroverze iz povijesti Jugoslavije. Sv. 2., Zagreb 1989., 444 str.

Eric HoBsBawm, Doba kapitala 1848-1875., Zagreb 1989., 280 str.

Dimitrije Dimo Vujović, Podgorička skupština 1918., Zagreb 1989., 288 str.

\section{0.}

Ljubo Boban, Kontroverze iz povijesti Jugoslavije. Sv. 3., Zagreb 1990., 356 str.

Jaroslav Šıdak; Vinko Foretić; Julije Grabovac; Igor Karaman; Petar Strčıć; Mirko Valentić, Hrvatski narodni preporod. Ilirski pokret, Zagreb 1990., 224 str.

Marijan MAтісKA, Agrarna reforma i kolonizacija u Hrvatskoj od 1945. do 1948., Zagreb 1990., 188 str.

\section{1.}

Peter BuRKE, Junaci, nitkovi i lude. Narodna kultura predindustrijske Evrope, Zagreb 1991., 260 str.

Božena VRANJEŠ-ŠOlJAN, Stanovništvo gradova Banske Hrvatske na prijelazu stoljeća. (Socijalno-ekonomski sastav i vodeći slojevi 1890-1914), Zagreb 1991., 298 str.

\section{2.}

Josef Matuz, Osmansko Carstvo, Zagreb 1992., 224 str.

\section{(Su)urednik Biblioteke Povijest i historija}

(Igor KaRAman; Drago Roksandić)

(Naprijed - Ljevak, Zagreb)

\section{1.}

Mato ARTuKović, Ideologija srpsko-hrvatskih sporova (Srbobran 1894-1902), Zagreb 1991., 284 str.

Drago Roksandić, „Predgovor“ (VII-XV)

Igor KARAMAN, Industrijalizacija građanske Hrvatske 1800.-1941., Zagreb 1991., 304 str. 
1995.

István Bıвó; Tibor Huszár; Jenő Szűcs, Regije evropske povijesti (preveli Eva Grlić, Igor Karaman i Arpad Vicko), Zagreb 1995., 230 str.

1997.

Horst HaselsteIner, Ogledi o modernizaciji u Srednjoj Europi (prevela Andrea Bjeloš), Zagreb 1997., 424 str.

Drago RoKSANDIć, „Horst Haselsteiner: Srednjoeuropski pisac i njegovo djelo“ (7-28)

Karl KASER, Slobodan seljak i vojnik. Vol I.: Rana krajiška društva (1545 - 1754.); Vol. II.: Povojačeno društvo (1754 - 1881.) (preveo Josip Brkić), Zagreb 1997., $272+254$ str. + kartografski prilog

Drago Roksandić, „Predgovor. Dijaloški o povijesti Vojne krajine u Hrvatskoj“ (7-13)

1999.

Arnold Suppan, Oblikovanje nacije u građanskoj Hrvatskoj (1835.-1918.) (preveo Josip Brkić), Zagreb 1999., 372 str.

2001.

Lynn Hunt (ur.), Nova kulturna historija (prevele Anamarija Hucika, Sanda Stepinac, Marina Škrabalo i Sanja Zubak; prijevod redigirala Nada Brnardić), Zagreb 2001., 320 str.

„Ovaj je prijevod najvećim svojim dijelom nastao u prevoditeljskoj radionici na predmetu Opća povijest novog vijeka (I.) na Odsjeku za povijest Filozofskog fakulteta u Zagrebu, koju je vodio prof. dr. Drago Roksandić." (6)

2003.

Iván BeREND; György RÁNkı, Evropska periferija i industrijalizacija 1780 - 1914 (prevela Lelija Sočanac), Zagreb 1996., 244 str.

\section{Urednik Biblioteke Homines, tempora, loci}

(Barbat, Zagreb)

\section{5.}

Péter Hanák (ur.), Povijest Mađarske (preveli Drago Roksandić i Veljka Čolić-Peisker), Zagreb 1995., 308 str.

Igor Karaman; Drago Roksandić (recenzenti)

Drago Roksandić, „Prepoznavanje poznatog. Uz prvu povijest Mađarske na hrvatskom jeziku“ (9-18)

\section{6.}

Giuliano Procaccl, Povijest Talijana (preveo Damir Grubiša), Zagreb 1996., 336 str.

Damir GrubišA; Drago RoksAndić (ur.)

Damir GrubišA; Drago RokSANDIĆ (recenzenti) 
Damir GrubišA; Drago Roksandić, „Metodički problemi sinteze povijesti Italije. (Kritički uvod u Procaccijev pristup povijesti Talijana)" (VII-XIX)

Charles Sellers; Henry May; Neil R. McMıllen, Povijest Sjedinjenih Američkih Država (preveli Neđeljka Batinović i Nenad Popović), Zagreb 1996., 472 str.

Damir Grubiša; Drago RoKSANDić (ur.)

Damir Grubiša; Drago RoKSANDIĆ (recenzenti)

Damir GrubišA; Drago RoksandiĆ, „Mistifikacije i realnosti američke povijesti. Kritički uvod u povijest SAD“ (VII-XXI)

1997.

Catherine Wendy Bracewell, Senjski uskoci. Piratstvo, razbojništvo i sveti rat na Jadranu u šesnaestom stoljeću (preveli Nenad Popović i Mario Rossini), Zagreb 1997., 320 str.

Mario StreCha, Katoličko hrvatstvo. Počeci političkog katolicizma u banskoj Hrvatskoj (1897. - 1904.), Zagreb 1997., 260 str.

Erich Zöllner; Therese Schüssel, Povijest Austrije (prevele Vlatka-Ana Dujić i Sonja Ledinčić), Zagreb 1997., 360 str.

Drago RoksAndić, "Austrija u trajanjima. Erich Zöllner i njegovo djelo“ (XI-XXXI)

\section{8.}

Jacques Le Rider, Mitteleuropa (prevela Vesna Pavković), Zagreb 1998., 292 str.

Jacques Le RIDER; Drago RokSANDIĆ, „Izbor. Srednjoeuropske varijacije“ (113-287)

Drago Roksandić, „Urednička napomena“ (115-116)

Jean-François NoëL, Sveto Rimsko Carstvo (prevela Vesna Pavković), Zagreb 1998., 204 str.

Drago Roksandić, „Predgovor hrvatskom izdanju“ (VII-XIX)

Drago RoKSANDIĆ (stručna redaktura kronologije)

Vlatka-Ana Duנı́́; Sonja LeDINČıć, „Prilog kronologiji“ (101-194)

1999.

Jean CarPentier; François Lebrun (ur.), Povijest Francuske (prevela Vesna Pavković), Zagreb 1999., 400 str.

Ulf Dirlmeier; Andreas Gestrich; Ulrich Herrmann; Ernst Hinrichs; Christoph Klessmann; Jürgen ReuleCKE, Povijest Njemačke (prevele Vlatka-Ana Laco i Sanja Perković), Zagreb 1999., 316 str.

Drago RoksAnDIĆ, „Urednička napomena“ (VII-VIII)

\section{1.}

Nataša Štefanec, Heretik njegova veličanstva. Povijest o Jurju IV. Zrinskom i njegovu rodu, Zagreb 2001., 316 str.

\section{2.}

Robert Delort; François Walter, Povijest europskog okoliša (prevela Vesna Pavković), Zagreb 2002., 300 str.

Drago RoKSANDić, „Pogovor. Ekohistorija: nova historiografska disciplina ili nova historijska znanost?" (263-274) 
Zrinka BıAžEvić, Vitezovićeva Hrvatska između stvarnosti i utopije. Ideološka koncepcija u djelima postkarlovačkog ciklusa Pavla Rittera Vitezovića (1652.-1713.), Zagreb 2002., 280 str.

Nikša Stančić, Hrvatska nacija i nacionalizam u 19. i 20. stoljeću, Zagreb 2002., 256 str. Marijan MATICKA; Drago RoKSANDIĆ; Tihomir CIPEK (recenzenti)

\section{3.}

Asa Brıccs, Socijalna povijest Engleske (prevela Vesna Pavković), Zagreb 2003., 354 str. Drago Roksandić, Triplex Confinium ili o granicama i regijama hrvatske povijesti 1500-1800, Zagreb 2003., 260 str.

Mladen TOMORAD, Egipat u Hrvatskoj. Egipatske starine u hrvatskoj znanosti i kulturi, Zagreb 2003., 236 str.

Conrad Totman, Povijest Japana, Zagreb 2003., 706 str.

Drago Roksandić (redaktor dijela prijevoda) (VI)

\section{Urednik Biblioteke Dialogica europea (Golden marketing - Tehnička knjiga, Zagreb)}

\section{4.}

Drago Roksandić (ur.), Uvod u komparativnu historiju. Izbor: Marc Bloch, Samuel N. Eisenstadt, Heinz-Gerhard Haupt, Jürgen Kocka, Jürgen Osterhammel, Adam Przeworski, Charles Ragin, Theda Skocpol, Margaret Somers, Henry Teune, Zagreb 2004., 304 str. Drago RoksAnDić, "Zahvala“ (7-8); „,Komparativna historija: izazovi i mogućnosti“ (9-34)

\section{5.}

Richard van Dülmen, Otkriće individuuma 1500. - 1800, Zagreb 2005., 144 str.

Drago Roksandić (recenzent)

Drago Roksandić, „Dülmenovo 'otkriće individuuma' i granice historijske znanosti“; "Izbor iz opusa Richarda van Dülmena“" (135-143)

\section{6.}

Maja BRKLJǍ̌ć́; Sandra PrLendA (ur.), Kultura pamćenja i historija, Zagreb 2006., 416 str. „Ova je knjiga realizirana u suradnji s Centrom za komparativnohistorijske i interkulturne studije Zavoda za hrvatsku povijest Filozofskog fakulteta u Zagrebu i dio je hrvatsko-francuskoga projekta 'Od Dunava do Mediterana: prostori, društva, kulturni transferi'." (2)

\section{7.}

Peter Stein, Rimsko pravo i Europa. Povijest jedne pravne kulture, Zagreb 2007., 184 str. Drago Roksandić (recenzent) 
2016.

Anette VÖlKer-RAsOr (ur.), Rani novi vijek, Zagreb 2016., 512 str.

Drago RoKSANDIĆ; Zrinka BLAŽEVIĆ (recenzenti i stručni redaktori)

Drago Roksandić, „Predgovor hrvatskom izdanju Ranoga novog vijeka“ (1-5)

\section{Urednik Biblioteke Triplex Confinium}

(Tipex, Zagreb)

2004.

Sanja LAZANIN, Uvod u njemačku paleografiju, Zagreb 2004., 124 str.

\section{5.}

Vesna Ivanović, Hrvati u bosansko-hercegovačkom društvu. Ljudi, krajolici, vremena, Zagreb 2005., 175 str.

Drago RoKSANDIĆ, „Riječ urednika“ (5-6)

2006.

Charles Dıєнl, Mletačka Republika, Zagreb 2006., 204 str.

Drago RoKsandić, „Pogovor. K modernim izvorištima venecijanističke historiografije“ (193-197)

\section{(Su)urednik izdanja "Prosvjeta d. o. o.“}

\section{3.}

André Blanc, Zapadna Hrvatska. Studija iz humane geografije, Zagreb 2003., 638 str.

Drago Roksandić, „Predgovor" (7-18)

Marko ŠARIĆ, Zapadna Hrvatska. Prilozi za bibliografiju, Zagreb 2003., 248 str.

Drago RoKsAnDić (redaktor)

„CD ROM, kao i istoimena publikacija uz koju je priložen, dopuna je knjizi André Blanca Zapadna Hrvatska. Studija iz humane geografije. Sadrži informacije o gotovo 6000 radova koji se bave 'zapadnohrvatskom regijom', nastalim u razdoblju od sredine 19. stoljeća do danas. Bibliografiju je moguće pretraživati prema nekoliko kriterija: imenu autora, mjestu i godini izdanja te ključnim riječima iz naslova djela. CD ROM izradili: Mariza i Amadeo Dujmović“

\section{5.}

Timothy WARE, Pravoslavna crkva, Zagreb 2005., 294 str.

Drago Roksandić, „Urednički pogovor. Pravoslavna crkva u hrvatskoj kulturi: povodom knjige Timothy Warea“" (269-270)

2006.

Tatjana PušKADIJA-RIBKIN, Emigranti iz Rusije u znanstvenom i kulturnom životu Zagreba, Zagreb 2006., 306 str.

Drago Roksandić (recenzent) 
2009.

Dane Pejnović, Zapadna Hrvatska. Socijalno-geografska preobrazba u drugoj polovini 20. stoljeća, Zagreb 2009., 100 str.

Drago RoKsandić (odgovorni ur.)

Drago Roksandić, „Predgovor“ (9-10)

2010.

Stephen J. PYNE, Vatra. Sažeta povijest (prevela Olga Škarić), Zagreb 2010., 217 str.

Branka Fulanović; Drago Roksandić (ur.)

Drago Roksandić, „Riječ na kraju“ (209-210)

\section{Centar za komparativnohistorijske i interkulturne studije Filozofskog fakulteta Sveučilišta u Zagrebu}

\section{Biblioteka Desničini susreti}

Drago Roksandić; Ivana CvıJović Javorina (urednici Biblioteke)

2010.

Ivan BAsIć, Od domus episcopi do Kule Jankovića. Prostorni razvoj Kule Stojana Jankovića u Islamu Grčkom, Zagreb 2010., 88 str.

Drago RoKsAnDić (ur.)

Drago Roksandić (recenzent)

Drago Roksandić; Ivana CviJović Javorina (ur.), Desničini susreti 2005. - 2008. Zbornik radova, Zagreb 2010., 316 str.

Drago RoKsANDIĆ, „Riječ unaprijed“ (7)

Drago Roksandić; Magdalena NajBar-Agičić; Ivana CviJović Javorina (ur.), Desničini susreti 2009. Zbornik radova, Zagreb 2010., 256 str.

Drago RoKSANDIĆ, "Riječ unaprijed“ (7)

Vidjeti: „Intelektualci i vlast 1954-1954: naučni skup“, Prosvjeta, 17/2010., br. 96, 26.

\section{1.}

Drago Roksandić; Ivana CviJović Javorina (ur.), Desničini susreti 2010. Zbornik radova, Zagreb 2011., 176 str.

Drago RoksAnDIĆ, „Riječ unaprijed“ (7)

\section{2.}

Drago RoksAndić; Ivana CVIJOVIĆ JAVORINA (ur.), Intelektualci i rat 1939.-1947. Zbornik radova s međunarodnog skupa Desničini susreti 2011., Zagreb 2012., 352 str.

Drago Roksandić; Ivana CVIJOVIĆ JAVORINA, „Riječ unaprijed“ (7-8)

Hannes Grandits, Obitelj i socijalne promjene u hrvatskim selima (18.-20. stoljeće). Studije slučaja Bobovac i Lekenik, Zagreb 2012., 292 str.

Drago RoKSANDIĆ; Marijeta RAJKOVIĆ IVETA (ur.)

Drago RoKSANDIĆ; Marijeta RA|KOVIĆ IVETA, „Hannes Grandits u hrvatskoj historiografiji i kulturnoj antropologiji (Urednički predgovor)“ (7-11) 


\section{3.}

Drago RoksAndić; Ivana CVIJOVIĆ JAVORINa (ur.), Intelektualci i rat 1939.-1947. Zbornik radova s međunarodnog skupa Desničini susreti 2012. dio 1. + dio 2., Zagreb 2013., 1-292 + 293-586 str.

Drago RoKsanDić; Ivana CVIJOVIĆ JAVORINA, „U Uremenu netrpeljivih. Intelektualci i rat 1939. - 1947. Predgovor" (9-40)

\section{4.}

Drago Roksandić; Marijeta RajKović Iveta; Tihana Rubić (ur.), Kula Jankovića. Spomenik kulture - pokretačč održivog razvoja Ravnih kotara. Baština, interkulturalizam i revitalizacija. Zbornik radova, Zagreb 2014., 176 str.

Drago RoKsAnDIĆ; Marijeta RAJKOVIĆ IVETA; Tihana RuBIĆ, , Regionalna baština u europskoj perspektivi. Umjesto predgovora" (7-8)

\section{5.}

Drago Roksandić; Ivana CviJović Javorina (ur.), Vladan Desnica i Split 1920. - 1945. Zbornik radova sa znanstvenog skupa Desničini susreti 2014., Zagreb 2015., 390 str.

Drago Roksandić; Ivana CvJJović JAVoRINA, „Riječ unaprijed“ (7-12)

Catherine Horel, Vojnici između nacionalnih fronti. Ukidanje Vojne krajine i razvoj Kraljevskoga ugarskog domobranstva u Hrvatskoj i Slavoniji 1868. - 1914. (prevela Ivana Cvijović Javorina) (ur. Drago Roksandić), Zagreb 2015., 210 str.

Drago RoKsandić, „Pogovor hrvatskom izdanju“ (173-177)

\section{6.}

Drago Roksandić; Ivana Cvijović Javorina (ur.), Split i Vladan Desnica i Split 1918. - 1945.: Umjetničko stvaralaštvo između kulture i politike. Zbornik radova sa znanstvenog skupa Desničini susreti 2015., Zagreb 2016., 510 str.

Drago Roksandić; Ivana CvıJović JAvorINA, „Splitski panoptikum između krajeva dvaju svjetskih ratova" (7-20)

\section{7.}

Drago RoKSANDIĆ (ur.), Hrvatsko-srpski/srpsko-hrvatski interkulturalizam danas. Zbornik radova s međunarodnog znanstvenog skupa Desničini susreti 2016., Zagreb 2017., 368 str. Drago Roksandić, „Hrvatsko-srpski/srpsko-hrvatski interkulturalizam danas i jučer. Predgovor“ (7-10)

\section{8.}

Ivana Cvijović Javorina; Drago Roksandić (ur.), Smrt u opusu Vladana Desnice i europskoj kulturi: poetički, povijesni i filozofski aspekti. Zbornik radova s međunarodnog znanstvenog skupa Desničini susreti 2017., Zagreb 2018., 518 str.

Ivana CVIJović JaVorINA; Drago Roksandić, "O smrti na Desničinim susretima. Predgovor“ (9-22) 


\section{Biblioteka Dijalog s povodom \\ Drago RoKSANDıć (urednik Biblioteke)}

2009.

/Sima M. ĆIRKOvić/ Drago RokSANDić, Dijalog s povodom / „Srbi među europskim narodima“, Zagreb 2009., 40 str.

Milliam M. Johnston/ Filip ŠImetın ŠEGvić, Dijalog s povodom / "Austrijski duh" - prije i poslije, Zagreb 2009., 44 str.

\section{1.}

Dijalog s povodom 3 / Nova dubrovačka historiografija: dr. sc. Nenad Vekarić i suradnici, Zagreb 2011., 62 str.

Drago Roksandić, „Dijalog s povodom 3 / Nova dubrovačka historiografija: dr. sc. Nenad Vekarić i suradnici: nekoliko napomena o motivima" (3-9)

\section{2.}

/Natalie Zemon Davis/ Nikolina ŠImetın ŠEgvić; Filip ŠImetın ŠEGvić, Dijalog s povodom 4 / Putujući između centra i margina, Zagreb 2012., 90 str.

\section{3.}

Dijalog s povodom 5 / Vladan Desnica i Desničini susreti: Pogled unatrag, pogled unaprijed, Zagreb 2013., 218 str.

Drago RoKSANDIĆ; Ivana CVIJOVIĆ JAVORINA (ur.)

Drago RoksAndić; Ivana CVIJOVIĆ JAVORINA, „Predgovor“ (9-11)

Branimir JANKOvIĆ (prir.), Dijalog s povodom 6 / Intelektualna historija, Zagreb 2013., 210 str.

Branimir JANKOVIĆ (ur.)

Branimir Janković; Drago RoKSANDIĆ (stručna redaktura prijevoda)

Drago Roksandić, „Šansa koja obvezuje. Povodom Intelektualne historije“ (7-10)

/Marc Ferro/ Tomislav BranĐolica; Marko Lovrić; Filip Šimetin ŠEGvić, Dijalog s povodom 7

/ Slika u povijest, povijest u slici: „pokretna“ historija, Zagreb 2013., 100 str.

\section{5.}

Mihael Antolović (prir.), Dijalog s povodom 8 / Intelektualna autobiografija i historijska antropologija Arona Gureviča, Zagreb 2015., 166 str.

2016.

Ivana CVIJOvić Javorina, Dijalog s povodom 9, I "Od ovih je njemački jezik za nas bez dvojbe najvažniji..." Prilozi za povijest nastave njemačkog jezika i studija germanistike na Mudroslovnom fakultetu u Zagrebu 1876. - 1904., Zagreb 2016., 162 str.

Drago RoKSANDić (ur.), „Profesionalno i dijaloški. Urednički pogovor“ (152-155) 


\section{Biblioteka Desničini susreti. Program rada / sažeci izlaganja Drago RoKsANDIĆ (urednik Biblioteke)}

\section{9.}

Desničini susreti 2009. Intelektualci i vlast, 1945.-1954. Program rada / sažeci izlaganja, Zagreb 2009., 44 str.

2010.

Desničini susreti 2010. Ideologija vlasti i ideologičnost teksta. Program rada / sažeci izlaganja, Zagreb 2010., 40 str.

\section{1.}

Desničini susreti 2011. Intelektualci i rat, 1939.-1947. godine. Program rada / sažeci izlaganja, Zagreb 2011., 50 str.

Drago RoKSANDIĆ; Branimir JANKOVIĆ (ur.)

\section{2.}

Desničini susreti 2012. Intelektualci i rat, 1939.-1947. godine. Program rada / sažeci izlaganja, Zagreb 2012., 84 str.

Drago RoKSANDIĆ; Branimir JANKOvić (ur.)

\section{3.}

Desničini susreti 2013. Intelektualac danas. Program rada / sažeci izlaganja, Zagreb 2013., 66 str.

Drago Roksandić; Filip ŠIMEtIN ŠEgvić; Nikolina ŠIMEtIN ŠEgvić (ur.)

\section{4.}

Desničini susreti 2014. Vladan Desnica i Split (1920. - 1945.). Program rada / sažeci izlaganja, Zagreb 2014., 72 str.

Drago Roksandić; Filip ŠImetIN ŠEgvić; Nikolina ŠIMETIN Š́egvić (ur.)

\section{5.}

Desničini susreti 2015. Split i Vladan Desnica (1918. - 1945.): umjetničko stvaralaštvo između kulture i politike. Program rada / sažeci izlaganja, Zagreb 2015., 74 str.

Drago RoKSANDić; Ivana CviJOvić Javorina (ur.)

\section{6.}

Desničini susreti 2016. Hrvatsko-srpski/srpsko-hrvatski interkulturalizam danas. Povodom 110. obljetnice rođenja Vladana Desnice. Program rada / sažeci izlaganja, Zagreb 2016., 78 str. Drago RoksAndić; Goran Korov (ur.) 


\section{7.}

Desničini susreti 2017. Smrt u opusu Vladana Desnice i europskoj kulturi - poetički, povijesni i filozofski aspekti. Program rada / sažeci izlaganja, Zagreb 2017., 84 str.

Drago Roksandić; Matko GıobaČnIK; Vladan Bač̌te (ur.)

\section{8.}

Desničini susreti 2018. Zagreb 1924. - 1930. i 1945. - 1967. Društvo, kultura, svakodnevica. Program rada / sažeci izlaganja, Zagreb 2018., 84 str.

Tomislav BranĐolicA; Filip ŠImetin ŠEGVIĆ (ur.)

\section{Biblioteka Colloquia}

(Drago RoKsandić, urednik Biblioteke)

\section{1.}

Colloquia 1 / Hrvati i Srbi u Habsburškoj Monarhiji u 18. stoljeću: interkulturni aspekti „prosvijećene“ modernizacije, Zagreb 2011., 40 str.

Drago RoKsandić; Zrinka Blažević (ur.)

Colloquia 2 / Kako poučavati o izgrađivanju Europe u vrijeme integracije zemalja europskog Jugoistoka? Stajališta europskih povjesničara, Zagreb 2011., 44 str.

Colloquia 3 / Ciklus javnih predavanja "Vojna krajina u suvremenoj historiografiji“, Zagreb 2011. - 2012., 50 str.

\section{2.}

Colloquia 4 / Znanstveni kolokvij "Glinska crkva Presvete Bogorodice“, 29./30. srpnja - 4./5. kolovoza 1941.: svjedočanstva i kultura sjećanja, Zagreb 2012., 62 str.

Colloquia 5 / Okrugli stol Desničini susreti i Kula Stojana Jankovića: iskustva i razvojne mogućnosti, Zagreb 2012., 84 str.

Drago Roksandić; Ivana CVIJOVIĆ JaVorina (ur.)

\section{Varia}

(programske knjižice, knjižice sažetaka i sl.)

1993.

Institut für die Wissenschaften vom Menschen / Institute for Human Sciences, Wien 1993. Vidjeti: „Programme. Forschungesschwerpunkte. Moderne Geschichte Zentraleuropas. Gesellschaft und Politik: Tony Judt; Drago Roksandic" (9-10)

\section{1.}

„Zavod za hrvatsku povijest poslije trideset godina, s usmjerenjem prema budućnosti / Institute of Croatian History Thirty years After, Heading Towards Future", Međunarodna znanstvena konferencija Povijesna istraživanja, studij povijesti i informatizacija I International Science Conference Historical Research, Study of History and Com- 
puterization, Zavod za hrvatsku povijest Odsjeka za povijest Filozofskog fakulteta u Zagrebu, Zagreb, 10. - 12. prosinca 2001., 1-2, 13-14. Hrvatski i engleski.

\section{3.}

„Ekohistorija podravskog višegraničja: novi pristupi starim temama / Umweltgeschichte des Mehrgrezgebiets in Podravina: alte Themes in neuer Sicht", u: Međunarodni znanstveni skup Ekohistorija podravskog višegraničja (od 15. stoljeća do 1918. godine) / Umweltgeschichte des Mehrgrezgebiets in Podravina (im Drautal) (von 15. Jahrhundert bis 1918), Zavod za hrvatsku povijest Odsjeka za povijest Filozofskog fakulteta Sveučilišta u Zagrebu - Povijesno društvo Koprivnica, Koprivnica, 13. - 15. studenoga 2003., 3-7. Hrvatski i njemački.

\section{6.}

„Trpeljivost netrpeljivih: francuska uprava i pravoslavlje u Dalmaciji i Boki (1806.-1809.), u: Međunarodni znanstveni skup Dalmacija za francuske uprave (1806-1813) (18 19. rujna 2006)“", Književni krug Split - Odjel za povijest Sveučilišta u Zadru - Zavod za znanstveni i umjetnički rad HAZU u Splitu, Split 2006., 31-33.

\section{9.}

"Nada Dimić (1923. - 1942.): pitanja o životu i smrti“, u: Sjećanja žena žrtava nacizma i nedemokratskih režima (ur. Sandra Prlenda), Centar za ženske studije, Zagreb 2009., 94-95.

\section{4.}

"How did it begin in Bihać, Karlovac and Zadar and how did it end...?", u: The Great War: Regional Approaches and Global Contexzs. International Conference on the Occasion of the First Centennial of the Beginning of World War One, Institut za istoriju et al., Sarajevo, 18. - 21. lipnja 2014., 38.

\section{7.}

Znanstveni skup s međunarodnim sudjelovanjem Pravoslavlje u Rijeci i na sjevernom Jadranu u ranom novom vijeku. Povodom 300. godišnjice povlastice cara i kralja Karla VI. (III.) pravoslavnima u Rijeci (1717.), Program rada / sažeci izlaganja, Rijeka 2017., 80 str. Drago Roksandić; Kosana Jovanović (ur.) /nb. Izvan serije Biblioteka Colloquia/

\section{8.}

"The Croatian parlementarians in 1848: An elite in the making", u: Les acteurs européens du 'printemps des peuples' 1848. Présentations des participants, Sorbonne Université, Paris, 31 mai - 2 juin 2018, 43-44. 
2019.

Branimir Brgles, Ljudi, prostor i mijene. Susedgradsko i donjostubičko vlastelinstvo 1450. 1700. Prilog istraživanju ruralnih društava, Biblioteka "Prilozi hrvatskom jezikoslovlju“, Institut za hrvatski jezik i jezikoslovlje, Zagreb 2019., 312 str.

Drago RoKsandić (ur.)

\section{PRIKAZI, OCJENE, RECENZIJE}

1973.

Zlatibor R. MıLovanović, Omladina i međunarodni odnosi, Institut društvenih nauka, Beograd 1973., 203 str.

Drago Roksandí́ (recenzent)

\section{7.}

/Đorđe Đurić; Dragutin PavličEvić, Sisak i banijski kraj: priručnik za učenike, Školska knjiga, Zagreb 1975., 43 str./, Istorijski glasnik, 1-2/1977., 172-174.

/Kosta MıLutinović, Štrosmajer i jugoslovensko pitanje, Institut za izučavanje istorije Vojvodine, Novi Sad 1976., 281 str./, Istorijski glasnik, 1-2/1977., 175-176.

/Gordana VıAJčıć, Osma konferencija zagrebačkih komunista, Školska knjiga - Institut za historiju radničkog pokreta Hrvatske, Zagreb 1976./, Pitanja, 3/1977., 98-100.

„Nastaje nova biblioteka marksističke literature“, Komunist, 35/1977., 1054.

1978.

Nladimir MAžURanić, Prinosi za hrvatski pravno-povjestni rječnik [pretisak], 2 sv., Informator, Zagreb 1975., 885 + 74 str./, Istorijski glasnik, 1-2/1978., 172-173.

/Inna Ivanovna LeščlLovSKAJA, Obščestveno-političeskaja borba v Horvatii 1848-1849, Moskva 1977./, Istorijski glasnik, 1-2/1978., 161-162.

/Gale StokEs, Legitimacy through Liberalism. Vladimir Jovanović and the Transformation of Serbian Politics, University of Washington Press, 1975., 279 str./, Istorijski glasnik, 1-2/1978., 162.

1979.

/Ivo PerIĆ, Dalmatinski sabor: 1861.-1912. (1918.) god., Posebna izdanja, Centar JAZU u Zadru, Zadar 1978., 233 str./, Pogledi, 3-4/1979., 227-229.

\section{0.}

/Đuro ZateZalo, Narodna vlast na Kordunu, Baniji i Lici (1941-1945), Historijski arhiv, Karlovac 1978., 622 str./, Istorijski glasnik, 1-2/1980., 173.

Nukosava Opačić-Lekić, Sava Mrkalj: život i djelo, Matica srpska, Novi Sad 1978., 178 str./, Istorijski glasnik, 1-2/1980., 153-154. 


\section{2.}

/Slavko GavRILović, Srem od kraja XVII do sredine XVIII veka, Filozofski fakultet u Novom Sadu - Institut za istoriju, Novi Sad 1979., 503 str./, Istorijski glasnik, 1-2/1982., 157-158.

/Nikša Stančić, Hrvatska nacionalna ideologija preporodnog pokreta u Dalmaciji. Mihovil Pavlinović i njegov krug do 1869., Sveučilište u Zagrebu - Centar za povijesne znanosti, Odjel za hrvatsku povijest, Zagreb 1980., 399 str./, Istorijski glasnik, 1-2/1982., 159-160.

/Ivo PeRIĆ, Dubrovačka periodika (1848-1918), Zavod za povijesne znanosti Istraživačkog centra JAZU, Dubrovnik 1980., 195 str./, Istorijski glasnik, 1-2/1982., 160-161.

/Gojko NıкоLı̌̆, Sava Mrkalj. Povijest o jednom stradalniku, Prosvjeta, Zagreb 1980., 119 str./, Istorijski glasnik, 1-2/1982., 147-151.

\section{3.}

„Život i djelo Jurja Križanića“"izložba/, Istorijski glasnik, 1-2/1983., 145-146.

/Milan Moguš; Josip VonČINA, „Salo debeloga jera libo azbukoprotres“ Save Mrkalja, Djela JAZU, knj. 58, JAZU - Skupština općine Karlovac, Karlovac 1983., 82 str./

"Srpskohrvatski“", NIN, br. 1718, 4. 12. 1983., 41.

\section{4.}

Nasilije KRESTIĆ, Srpskohrvatski odnosi i jugoslovenska ideja, 1860-1873. Studije i članci, Narodna knjiga, Beograd 1983., 484 str./ „Jugoslovenska baština“, NIN, br. 1724, 8. 1. 1984., 35-36.

/Savjetovanje o istoriografiji Bosne i Hercegovine 1945-1982, Posebna izdanja ANUBiH 65, Sarajevo 1983., 181 str./

„BiH, za sada, jedina“, NIN, br. 1727, 12. 2. 1984., 36-37.

/Đorđe Stanković; Drago Roksandić, Istorija srpskog naroda. knj. 6.: Od Berlinskog kongresa do ujedinjenja (1878-1918), Srpska književna zadruga, Beograd 1983., 679 str./ „Šesti tom tradicije i inovacije“, NIN, br. 1734, 25. 3. 1984., 31-33.

/Hrvatski biografski leksikon I / A-Bi, Jugoslavenski leksikografski zavod Miroslav Krleža, Zagreb 1983., 800 str./

„Kapitalna investicija, ali...", NIN, br. 1738, 22. 4. 1984., 35-36.

/Josip Horvat, Živjeti u Hrvatskoj 1900-1941. Zapisci iz nepovrata, Sveučilišna naklada Liber, Zagreb 1984., 352 str./

„Pristojno građanski“, NIN, br. 1742, 20. 5. 1984., 33-34.

Nojna krajina. Povijesni pregled - historiografija - rasprave, Sveučilišna naklada Liber Centar za povijesne znanosti Sveučilišta u Zagrebu, Odjel za hrvatsku povijest, Zagreb 1984., 476 str./

„Posle sto godina“, NIN, br. 1744, 3. 6. 1984., 38-39.

/,Naši razgledi“ - komplet '83: rasprava slovenskih intelektualaca o suvremenoj povijesnoj svijesti/

„Slovenija i historija“, NIN, br. 1757, 2. 9. 1984., 36-38. 
Mile Bocovıć, Katolička crkva i pravoslavlje u Dalmaciji za vrijeme mletačke vladavine, Kršćanska sadašnjost, Zagreb 1982., 187 str.; Marko Jačov, Venecija i Srbi u Dalmaciji u XVIII veku, Prosveta, Beograd 1984., 157 str./

„U grčko-rimskom stilu“, NIN, br. 1770, 2. 12. 1984., 38-39.

„Tradicija i inovacija“/Rubrika: „NIN-ovi kritičari biraju“/, NIN, br. 1774, 30. 12. 1984., 29.

\section{5.}

|Zbornik sjećanja. Zagreb 1941 - 1945., knj. 1-4, Gradska konferencija SSRNH, Zagreb 1982. $-1984 ., 348+400+341+438$ str./

„Zagreb 1941 - 1945“, NIN, br. 1777, 20. 1. 1985., 40.

/Spomen knjiga Srpskog privrednog društva ",Privrednik“, Udruženje Privrednikovih pitomaca „Vladimir Matijević", Beograd 1984., 1078 str./

„Izvanredna radnička građa“, NIN, br. 1787, 31. 3. 1985., 42.

/Antun MiHanović, Rech domovini od hasznovitozti piszanya vu domorodnom jeziku, Cymelia Croatica 2, Međunarodni slavistički centar SR Hrvatske, Zagreb 1985., 16 str./ "Opravdan povratak izvorima“, NIN, br. 1789, 14. 4. 1985., 41.

/Đuro ZateZALO, Četvrta konferencija KPH za okrug Karlovac 1945., Historijski arhiv u Karlovcu, Karlovac 1945., 230 str./

„Revolucija i 'incidenti'“, NIN, br. 1978, 16. 6. 1985., 43.

/Branislav ĐurĐev, Postanak i razvitak brdskih, crnogorskih i hercegovačkih plemena. Odabrani radovi, CANU, Titograd 1984., 205 str./

"Nauka i plemena“, NIN, br. 1803, 21. 7. 1985., 42.

/Petar Šimunović, Naša prezimena. Porijeklo - značenje - rasprostranjenost, Nakladni zavod Matice hrvatske, Zagreb 1985., 366 str./

„Bez unitarizma“, NIN, br. 1806, 11. 8. 1985., 35-36.

/Josip HRNČEvić, Svjedočanstva, Globus, Zagreb 1985., 255 str./

„Poverenje“, NIN, br. 1808, 25. 8. 1985., 38.

/Basil Davidson, Afrika u povijesti. Teme i osnove razvoja, Globus, Zagreb 1984., 264 str.; Roland Oliver; J. D. FAGE, Kratka povijest Afrike, Školska knjiga, Zagreb 1985., 291 str./ „Afrika, dva puta“, NIN, br. 1811, 15. 9. 1985., 29.

/II. Jugoslavensko-francuski kolokvij, Rektorat Sveučilišta u Ljubljani, 1985./

„Kolokvijum 'bez državljanstva'“, NIN, br. 1815, 13. 10. 1985., 33.

/Niccolò Machiavelu, Izabrano djelo, sv. I-II, Delo - Globus, Zagreb 1985., 518 + 483 str./ „Naš suvremenik“, NIN, br. 1819, 10. 11. 1985., 41-42.

/Marko JAČOV, „U okvirima razumne istorijske kritike“, NIN, br. 1777/

„Ipak, slabo i anahrono“/Polemika/, NIN, br. 1779, 3. 2. 1985., 25-26.

„Milan Radeka u srpskoj historiografiji“ ,Zbornik Matice srpske za istoriju, 31/1985., 79-80.

\section{6.}

Dragutin Pavličević; Filip PotrebicA; Rene Lovrenčić, Čovjek u svom vremenu 3. Udžbenik povijesti za VII razred osnovne škole, Školska knjiga, Zagreb 1986., 236 str.

Drago Roksandić (recenzent) 
Dragutin Pavličević; Filip PotreBICA; Rene Lovrenčić, Čovjek u svom vremenu 3. Povijesna čitanka za VII razred osnovne škole, Školska knjiga, Zagreb 1986., 160 str.

Drago RoKSANDIć (recenzent)

"Sve teže, sve bolje“ /Rubrika: „NIN-ovi kritičari biraju“/, NIN, br. 1827, 5. 1. 1986., 35-36. /Josip ADAmčEk i sur., Seljačke bune u Hrvatskoj u XVII stoljeću, Centar za povijesne znanosti Sveučilišta u Zagrebu, Odjel za hrvatsku povijest, Zagreb 1985., 646 str./

„Bune“, NIN, br. 1831, 2. 2. 1986., 41.

/Janko Pleterskı, Nacije, Jugoslavija, revolucija, Izdavački centar Komunist, Beograd 1985., 531 str./

"Opušteno o upuštenom“, NIN, br. 1834, 23. 2. 1986., 41-42.

/Latinka Perović, Srpski socijalisti 19. veka. Prilog istoriji socijalističke misli, knj. I-II, Rad, Beograd 1985., $317+354$ str./

"Obračun sa duhom palanke“, NIN, br. 1840, 6. 4. 1986., 40-41.

/Đorđe Stanković, Nikola Pašić i jugoslovensko pitanje 1-2, Beogradski izdavačko-grafički zavod, Beograd 1985., $238+307$ str./

„Pašić, ispit“, NIN, br. 1848, 8. 6. 1986., 44.

/Mirjana Gross, Počeci moderne Hrvatske. Neoapsolutizam u civilnoj Hrvatskoj i Slavoniji 1850 - 1860., Globus - Centar za povijesne znanosti Sveučilišta u Zagrebu, Odjel za hrvatsku povijest, Zagreb 1985., 521 str./

"(S)misao oslobađanja“, NIN, br. 1851, 29. 6. 1986., 45.

/Miroslav BertošA, Etos i etnos zavičaja, Čakavski sabor - Istarska naklada - „Otokar Keršovani“ - Edit, Pula - Rijeka 1985., 327 str./

"Živeti zajedno“, NIN, br. 1862, 7. 9. 1986., 41.

"Religija“, NIN, br. 1863, 14. 9. 1986., 31.

/Marko JaČov, Spisi Kongregacije za propagandu vere u Rimu o Srbima, 1622-1644, I, SANU, Beograd 1986., 696 str./

„Vatikan i Srbi“, NIN, br. 1869, 26. 10. 1986., 36.

/Znanstveni skup Komunistički pokret u Dalmaciji 1919. - 1950., Split, 22. - 24. X. 1986./ „Komunisti i Dalmacija“, NIN, br. 1870, 2. 11. 1986., 34-35.

/Fikreta Jelı́́-Butıć, Četnici u Hrvatskoj 1941-1945., Globus, Zagreb 1986., 271 str./ "Kokardom protiv Srba“, NIN, br. 1877, 21. 12. 1986., 41-42.

/Isidor KRŠNJAVI, Zapisci - iza kulisa hrvatske politike, sv. I-II, Mladost, Zagreb 1986./ „Kontroverza Kršnjavi“, Danas, 23. 12. 1986., 35-36.

\section{7.}

"Jugoslavija i prioritet" /Rubrika: „NIN-ovi kritičari biraju“/, NIN, br. 1879, 4. 1. 1987., 38. "Obnovljeni JIČ“, NIN, br. 1883, 1. 2. 1987., 30.

/Đorđe Zelmanović, Kadet Krleža. Školovanje Miroslava Krleže u mađarskim vojnim učilištima, Školske novine - Sveučilišna naklada Liber, Zagreb 1987., 175 str./

„Kadet Krleža“, NIN, br. 1886, 22. 2. 1987., 33.

/Znanstveni skup Bukovica u prošlosti, Zavod za povijesne znanosti i klasičnu filologiju Filozofskog fakulteta u Zadru, 21. i 22. V. 1987./

"Srpskohrvatski iz Bukovice“, NIN, br. 1901, 7. 7. 1987., 42-43. 
/Stare karte i atlasi Povijesnog muzeja Hrvatske. Katalog izložbe, Povijesni muzej Hrvatske, Zagreb 1987., 112 str./

"Slika svijeta“, Danas, br. 279, 23. 6. 1987., 45.

/Ivan Lučıć, O kraljevstvu Dalmacije i Hrvatske, Biblioteka Latina et Graeca, knj. 7, VPA, Zagreb 1986., 471 str./

„Istina i politika“, NIN, br. 1908, 26. 7. 1987., 38-40.

/Jakov Gelo, Demografske promjene u Hrvatskoj od 1780. do 1981., Globus, Zagreb 1987., 315 str./

„Hrvatska: vredno, kontroverzno“, NIN, br. 1915, 13. 9. 1987., 36.

/Kongres istoričara Jugoslavije u Prištini/

"Mimo provincija“/Rubrika: Kultura/, NIN, br. 1918, 4. 10. 1987., 30.

/Osječki časopis za književnost, umjetnost i društvena pitanja Revija (br. 8 - 9, 1987), posvećen Vuku Karadžiću/

„Vuk u Osijeku“, NIN, br. 1923, 8. 11. 1987., 31.

\section{8.}

„Istoriografija: Izraziti ‘naboj'“ /Rubrika: „NIN-ovi kritičari biraju“/, NIN, br. 1931, 3. 1. 1988., 30.

/Georg Ernest MARETić, Istorija srpske revolucije, „Filip Višnjić“, Beograd 1987., 295 str./

„Hrvatski plemić o srpskoj revoluciji“", NIN, br. 1933, 17. 1. 1988., 36-37.

Niktor Novak, Magnum tempus. Ilirizam i katoličko sveštenstvo. Ideje i sličnosti 1830 1849, Nova knjiga, Beograd 1987., 660 str./

„'Veliko doba' hrvatskog katoličanstva“, NIN, br. 1935, 31. 1. 1988., 41.

/Dimitrije Dimo Vujović, Prilozi izučavanju crnogorskog nacionalnog pitanja, Univerzitetska riječ, Nikšić 1987., 276 str./

„Protivstruja“, NIN, br. 1955, 19. 6. 1988., 40-41.

/Olga Popović, Stojan Protić i ustavno rešenje nacionalnog pitanja u Kraljevini SHS, Savremena administracija, Beograd 1988., 155 str./

„Srbijanski radikalizam“, Danas, br. 332, 28. 6. 1988., 41.

/Ive MAžURAn, Popis naselja i stanovništva u Slavoniji 1698. godine, JAZU, Zavod za znanstveni rad u Osijeku, Osijek 1988., 574 str./

„Rat i demografske promene“, NIN, br. 1970, 2. 10. 1988., 40.

/Mirjana Gross, Počeci moderne Hrvatske. Neoapsolutizam u civilnoj Hrvatskoj i Slavoniji 1850-1860, Centar za povijesne znanosti Sveučilišta u Zagrebu, Odjel za hrvatsku povijest - Globus, Zagreb 1985., 521 str./, Socialism in the World, 64/1988., 160-162. Engleski.

„Zbornik - dokaz prošlosti“, Glinski vjesnik, 13. 6. 1988., 6.

\section{9.}

"Između nauke i politike“/Rubrika: „NIN-ovi kritičari biraju“/, NIN, br. 1983, 1. 1. 1989., 32. 
Vladimir ŽERJAvIĆ, Gubici stanovništva Jugoslavije u drugom svjetskom ratu, Jugoslavensko viktimološko društvo, Zagreb 1989., 191 str.

Drago RoKSANDIĆ (recenzent)

1994.

"Chinesische Mauer. Kroatiens Mittellage und die Konkurrenz der Kulturen“, Frankfurter Allgemeine Zeitung br. 255, 2. 11. 1994., N5.

\section{7.}

„Prilozi za bibliografiju profesora Fedora Moačanina“, Prosvjeta. Novine za kulturu, 4/1997., br. $25,33$.

Felipe FernÀndeZ-Armesto, Narodi Europe, Naklada Zadro, Zagreb 1997., 414 str.

Drago RoKSANDIĆ (recenzent)

\section{8.}

/Alexander BucZYNSkı, Gradovi Vojne krajine. Vol. 1-2, Hrvatski institut za povijest, Zagreb 1997., $356+378$ str./

„Vojna krajina - drugi put“, Vijenac, VI/1998., br. 122, 22-23.

/Francis VıolıCH, The Bridge to Dalmatia. A Search for the Meaning of Place, Johns Hopkins University Press, Baltimore - London 1998., 352 str./, H-Urban, H-Net Reviews, September 1998. (https://www.h-net.org/reviews/showpdf.php?id=2315)

2000.

Hrvoje Petrić, Koprivnica na razmeđu epoha (1765 - 1870), Biblioteka Historia Croatica 20, Nakladna kuća „Dr. Feletar“ - Zavod za hrvatsku povijest Filozofskog fakulteta u Zagrebu, Koprivnica - Zagreb 2000., 92 str.

Drago Roksandić (recenzent)

\section{1.}

„O izdavačkoj djelatnosti SKD 'Prosvjeta': s prve sjednice Glavne redakcije SKD 'Prosvjeta', 7. 7. 2000.", Prosvjeta. Novine za kulturu, 8/2001., br. 43/44, 16-17.

\section{2.}

Željko Holjevac, Gospić u Vojnoj krajini (1689. - 1712. - 1881.) (Prilog slici gospićke povijesti), Hrvatski zemljopis, Zagreb 2002., 99 str.

Drago Roksandić (recenzent)

Michael HowARD, Rat u europskoj povijesti (prevela Magdalena Najbar-Agičić), Srednja Europa, Zagreb 2002., 173 str.

Drago Roksandić (recenzent) 
2003.

„Kula Jankovića: inicijativa obnove i oživljavanja Kule Stojana Jankovića i sela Islam Grčki“, Prosvjeta. Novine za kulturu, 10/2003., br. 55, 29-31.

Mark MAZOWER, Balkan: kratka povijest (preveo Krešimir Krnic), Srednja Europa, Zagreb 2003., 182 str.

Drago Roksandić (recenzent)

Suzana LečEk, Seljačka obitelj u sjeverozapadnoj Hrvatskoj 1918.-1941., Srednja Europa - Hrvatski institut za povijest, Podružnica za povijest Slavonije, Srijema i Baranje, Zagreb 2003., 535 str.

Drago Roksandić (recenzent)

Čedomir VIŠNıIć, Partizansko ljetovanje. Hrvatska i Srbi 1945.-1950., SKD Prosvjeta, Zagreb 2003., 487 str.

Drago Roksandić (recenzent)

Hannes Grandits, Obitelj i socijalne promjene u hrvatskim selima (18. - 20. stoljeće). Studije slučaja Bobovac i Lekenik (prevela Barbara Dukić) (ur. Drago Roksandić; Marijeta Rajković Iveta), Biblioteka Desničini susreti, sv. 7, Filozofski fakultet Sveučilišta u Zagrebu, Centar za komparativnohistorijske i interkulturne studije, Odsjek za etnologiju i kulturnu antropologiju - FF press, Zagreb 2012., 292 str.

Drago Roksandić (recenzent)

Mirela Slukan Altić, Povijesna kartografija. Kartografski izvori u povijesnim znanostima, Meridijani, Samobor 2003., 495 str.

Drago Roksandić (recenzent)

\section{4.}

"Reakcija na diskusiju/polemiku Nikole Žutića“, u: Dijalog povjesničara - istoričara 8: Zadar, 26.-28. septembra 2004. (prir. Igor Graovac; Hans-Georg Fleck), Friedrich Naumann Stiftung, Zagreb 2004., 199.

/Larry Wolff, Venice and the Slavs. The Discovery of Dalmatia in the Age of Enlightenment. Stanford University Press, Stanford 2001., 408 str./, Austrian History Yearbook, 35/2004., 293-294.

A. J. P. TAYlor, Uzroci Drugog svjetskog rata, Znanje, Zagreb 1994., 362 str.

Drago Roksandić (recenzent)

\section{5.}

„Baština u otvorenoj povijesnoj perspektivi“, Školski vjesnik, 1-2/2005., 136-139.

Zbornik Ivana Mimice u povodu 70. rođendana (ur. Živko Bjelanović; Šime Pilić), Biblioteka Školskog vjesnika 1, Split 2003., 280 str.

(Riječ na predstavljanju Zbornika u Splitu, u lipnju 2004. godine u organizaciji Školskog vjesnika i Visoke učiteljske škole Sveučilišta u Splitu.)

Giuseppe MAZZıNı, Slavenska pisma, Srednja Europa, Zagreb 2005., 119 str.

Drago Roksandić (recenzent) 
Jelena LAKUš, Izdavačka i tiskarska djelatnost na dalmatinskom prostoru (Zadar, Split, Dubrovnik) u prvoj polovici 19. stoljeća (1815.-1850.). Bibliografija monografskih i serijskih publikacija - građa, Književni krug, Split 2005., 386 str.

Drago Roksandić (recenzent)

Josip Ante Soldo, Grimanijev zakon. Zakon za dalmatinske krajine iz 1755./56. godine (prir. Nikša Stančić), Golden marketing - Tehnička knjiga - FF Press, Filozofski fakultet Sveučilišta u Zagrebu, Zavod za hrvatsku povijest, Zagreb 2005., 174 str.

Drago RoKsandić (recenzent)

\section{6.}

Damir MATANOVIĆ, „Nametnuta dvojnost: nastanak slobodnog vojnog komuniteta Vinkovci (1765.-1787.)“, Scrinia slavonica, 6/2006., br. 1, 183-193.

Drago Roksandić (recenzent)

Borislav GrGIN, Rumunjske zemlje u srednjem i ranom novom vijeku, FF press, Zagreb 2006., 108 str.

Drago Roksandí́ (recenzent)

Mirela SlukAn Altić, Povijesna geografija Kosova, Golden marketing - Tehnička knjiga, Zagreb 2006., 160 str.

Drago Roksandić (recenzent)

2007.

Ines SABOtıč, Stare zagrebačke kavane i krčme s kraja 19. i početaka 20. stoljeća, AGM Institut društvenih znanosti „Ivo Pilar“, Zagreb 2007., 233 str.

Drago RoKsandić (recenzent)

Mirela StuKan Altić, Povijesna geografija rijeke Krke. Kartografska svjedočanstva, Javna ustanova "Nacionalni park Krka“, Znanstveni projekt Titius, Šibenik - Zagreb 2007., 223 str. Drago Roksandić (recenzent)

\section{8.}

Giovanni RADOSSI, La toponomastica istriota storica, moderna e comparata della città e del territorio di Rovigno d'stria, Collana degli Atti, n. 28, Centro di Ricerche Storiche, Rovigno 2008., 442 str. +3 topografske karte

Drago Roksandić (recenzent)

2010.

Ian Gordon Simmons, Globalna povijest okoliša: od 10000. pr. Kr. do 2000. n. Kr. (preveo s engleskoga Damjan Lalović), Disput, Zagreb 2010., 306 str.

Drago Roksandić (recenzent)

Mirjana KASAPOvić, Politički sustav i politika Izraela, Politička kultura, Zagreb 2010., 328 str. Drago Roksandić (recenzent)

„Riječ na promociji godišnjaka Titius br. 2/2009“, Godišnjak Titius, 3/2010., br. 3, 251-252. 


\section{1.}

Lazo StaRČEvić, Protiv zaborava. Bilješke iz 1984., Izvori, Zagreb 2011., 127 str.

„Ulomci iz recenzije prof. dr. sc. Drage Roksandića“ (prednja klapna)

"Istarska toponomastika u povijesnom kontekstu“, Radovi Zavoda za hrvatsku povijest Filozofskog fakulteta Sveučilišta u Zagrebu, 43/2011., 498-499.

Drago Roksandić (recenzent)

\section{2.}

Hrvoje Petrić, Pogranična društva i okoliš. Varaždinski generalat i Križevačka županija u 17. stoljeću, Meridijani - Društvo za hrvatsku ekonomsku povijest i ekohistoriju, Samobor - Zagreb 2012., 436 str.

Drago Roksandić (recenzent)

„Koliko je bila doista 'nova' Nova Evropa?"“ (Nova Evropa 1920-1941)“, Književna istorija, XLIV/2012., br. 146, 225-241.

/Nova Evropa 1920-1941. Zbornik radova (ur. Marko Nedić; Vesna Matović), Institut za knjǐ̌evnost i umetnost, Beograd 2010., 702 str./

\section{3.}

"Croatie, la voici. 22. festival Est-Ouest, Die (departman Drôme), 19.-30. rujna 2012., posvećen Hrvatskoj", Radovi Zavoda za hrvatsku povijest Filozofskog fakulteta Sveučilišta u Zagrebu, 45/2013., 274-278.

Kamik na kunfinu: granične oznake u istarskim šumama / Pietre sui confini: i cippi terminali nei boschi istriani, Monografije i katalozi 22, Arheološki muzej Istre, Pula 2013., 287 str. Drago RoKsAndí́ (recenzent)

\section{4.}

Sanja Lazanin, Slika Drugoga i pismo o sebi. Grof Josip Rabatta (1661. - 1731.) o Hrvatskoj i sebi, Srednja Europa, Zagreb 2014., 275 str.

Drago Roksandić (recenzent)

Kristina Miıković Šarić, Josip Jelačić u Prvoj banskoj pukovniji (1841. - 1848.). Prilozi za povijest političke ideologije Josipa Jelačića, Plejada, Zagreb 2014., 197 str.

Drago Roksandić (recenzent)

\section{5.}

Jacques LE Goff, Treba li povijest zaista dijeliti na razdoblja? (prevela s francuskoga Gordana V. Popović; stručna redaktura Hrvoje Gračanin), TIM press, Zagreb 2015., 122 str. Nenad Ivić; Drago Roksandić (recenzenti)

Perica DomıJAN, „Dubrovački Židovi u sudskim procesima 18. stoljeća“, Zbornik Sveučilišta u Dubrovniku, 2/2015., 23-54.

Drago RoKSANDIĆ (recenzent) 
2016.

Mirela Stukan Altić, Gomirje: Povijest, identitet i fenomeni prožimanja, LAG Gorski Kotar - Naklada Kvarner, Gomirje - Rijeka 2016., 272 str.

Drago Roksandić (recenzent)

Alfred J. Rieber, The Struggle for the Eurasian Borderlands: From the Rise of Early Modern Empires to the End of First World War, Cambridge University Press, New York 2014., 648 str.

Drago RokSANDić, „Euroasiatic empires and global history. Roksandić legge Rieber“, Storica. Rivista quadrimestrale, 21/2015, br. 61-62, 219-230. Engleski.

2018.

Lazo Starčević, Protiv zaborava. Dnevničke bilješke 1984. - 1990., Izvori, Zagreb 2018., 398 str.

Drago RoksAndić (recenzent; ulomak na stražnjim koricama)

\section{E. IZDANJA IZVORA}

\section{3.}

„Tri izvora iz francuskih arhiva s početka XIX stoljeća“, Mešovita građa (Miscellanea), 11/1983., 135-158.

„Engelshofenov Regulament iz 1747. godine (Prilog za povijest Slavonske krajine u XVIII stoljeću", Zbornik Centra za društvena istraživanja Slavonije i Baranje, 20/1983., br. 1, 235-253.

/„Regulament" transkribirala Tatjana Subotin./

"Jedan krajiški popis iz Vojne Hrvatske (La Croatie militaire)", Zbornik Centra za društvena istraživanja Slavonije i Baranje, 20/1983., br. 1, 255-262.

\section{5.}

„Milan Radeka. Nekoliko priloga o Savi Mrkalju“, Zbornik Matice srpske za istoriju, 31/1985., 65-78.

\section{7.}

„Utješenovićev spis 'O patrijarhalnom životu naroda jugoslavjanskog'“, Historijski zbornik, 40/1987., br. 1, 239-245.

„'Temeljite uprave za Karlovacsku, Varasdinsku, Banovsku, Slavonsku, i Banatsku Vojne Granice' iz 1807. godine“, Radovi Zavoda za hrvatsku povijest Filozofskog fakulteta Sveučilišta u Zagrebu, 20/1987., 195-213.

\section{8.}

„Vjernici i sveštenstvo Plaščanske eparhije u 1810. godini“, Zbornik radova o povijesti i kulturi srpskog naroda u Socijalističkoj Republici Hrvatskoj, 1/1988., 119-136. 
1989.

Drago Roksandić; Josip Bratulić, „Telegraf službenički Šime Starčevića iz 1811. godine, Povijesni muzej Hrvatske, Zagreb 1989.

"Iliričko" izdanje lista Le télégraphe officiel, službenog glasila Ilirskih pokrajina. Tiskano u povodu izložbe „Hrvatske zemlje i francuska revolucija“. U prilogu je i tekst Josipa Bratulića „Jezik i grafija Šime Starčevića u 'Telegrafu službeničkom'“.

1991.

„Kartografski izvori za povijest Slavonije od 16. do 18. stoljeća", u: Peti znanstveni sabor Slavonije i Baranje. Zbornik radova, Osijek 1991., 196-216, 388-390.

\section{5.}

„Neobjavljeno pismo Gojka Nikoliša. Iz logora u Francuskoj 'Seljačkom kolu' u Sjeničaku iz 1939. godine“, Prosvjeta. Narodni srpski kalendar za godinu 1995. (ur. Drago Kekanović; Čedomir Višnjić), SKD Prosvjeta, Zagreb 1995., 139-147.

„Plaščani u revoluciji 1848. godine“, Prosvjeta. Novine za kulturu, 2/1995., br. 13/14, 14-18. (Nadnaslov: „Izvori za pravnu povijest Srba u Hrvatskoj (I.)“)

(„Zahtevanje naroda cete Plaščanske Ogulinske kraine“ (Plaški, 22. 5. 1848.) i „Narodu hervatskome i serbskome u trojednoj kraljevini Dalmacie, Hervatske i Slavonie ljubezni pozdrav. (...) Jelačić, Ban“.)

„Habsburgovci, merkantilistički interesi i Karlovačka mitropolija“, Prosvjeta. Novine za kulturu, 2/1995., br. 15/16, 12-13. (Nadnaslov: "Izvori za pravnu povijest Srba u Hrvatskoj (II.)“)

(Povlastice Karla Šestog Riječkoj pravoslavnoj općini 1717. godine.)

\section{6.}

"'Dobro uredjeno opštestvo'. O temeljnim ljudskim pravima na Temišvarskom saboru 1790.“, Prosvjeta. Novine za kulturu, 3/1996., br. 17/18, 20-23. (Nadnaslov: „Izvori za pravnu povijest Srba u Hrvatskoj (III.)“)

\section{7.}

„Pravna svijest i pravna kultura Dositeja Obradovića: Gerhard Neweklowsky, 'Dositej Obradović, Leben und Abendteuer, Erster Teil, Leipzig 1783. Konkordanzen. Wortlisten', Wien 1985.)“, Prosvjeta. Novine za kulturu, 4/1997., br. 23/24, 28-29. (Nadnaslov: „Izvori za pravnu povijest Srba u Hrvatskoj (IV.)"

\section{8.}

Simo Rajlć; Drago Roksandić, „Dokument 6: Amandmani na Nacrt Ustava Republike Hrvatske", Prosvjeta. Srpski narodni kalendar za godinu 1998. (ur. Čedomir Višnjić), SKD Prosvjeta, Zagreb 1998., 139-142.

„Dokument 8: Društvo hrvatsko-srpskog prijateljstva“, Prosvjeta. Srpski narodni kalendar za godinu 1998. (ur. Čedomir Višnjić), SKD Prosvjeta, Zagreb 1998., 146-147. 
„Dokument 12: Inicijativni odbor za osnivanje Srpskog narodnog sabora“, Prosvjeta. Srpski narodni kalendar za godinu 1998. (ur. Čedomir Višnjić), SKD Prosvjeta, Zagreb 1998., 162-163.

\section{9.}

Drago RoKsAndić; Čedomir VIšnıÍ́ (ur.); Zrinka BLAŽEvIĆ (prijepis izvora i prijevod s latinskog), Statuta Valachorum. Prilozi za kritičko izdanje, SKD Prosvjeta, Zagreb 1999., 72 str.

Drago Roksandić, „Statuta Valachorum. Radno izdanje 1999.“ (7-8)

Mirela Slukan, Kartografski izvori za povijest Triplex Confiniuma / Cartographic Sources for the History of the Triplex Confinium / Kartographische Quellen zur Geschichte des Triplex Confinium, Hrvatski državni arhiv - Zavod za hrvatsku povijest Filozofskog fakulteta Sveučilišta u Zagrebu, Zagreb 1999.

Drago Roksandič (recenzent); Drago Roksandić, „Uvod“ (13)

„Priručnik o vojnim krajinama u Dalmaciji iz 1783.", Ljetopis SKD Prosvjeta, 4/1999., 11-41.

Prijevod Priručnika s talijanskog Olga Diklić.

2000.

„Bogom izabrani narod ili vjerska trpeljivost i netrpeljivost hrvatskog i srpskog etnokonfesionalnog nacionalizma u hrvatsko-slavonskoj Vojnoj krajini u proljeće 1848. - I.“, Prosvjeta. Novine za kulturu, 7/2000., br. 37/38, 16-24.

„Bogom izabrani narod ili vjerska trpeljivost i netrpeljivost hrvatskog i srpskog etnokonfesionalnog nacionalizma u hrvatsko-slavonskoj Vojnoj krajini u proljeće 1848. - II.“, Prosvjeta. Novine za kulturu, 7/2000., br. 39/40, 16-24.

\section{1.}

„Talijanska pisma Karla Horvata Milanu Grloviću (1904.-1908.)“, Cris, 3/2001., 15-29.

\section{2.}

„Srbi u Hrvatskoj u hrvatskoj i srpskoj historiografiji: problemi usporedbe dvije interpretacijske tradicije“, Dijalog povjesničara - istoričara 5 (ur. Hans-Georg Fleck; Igor Graovac), Friedrich-Naumann-Stiftung, Zagreb 2002., 211-230.

„Evropske šanse Hrvatske i Srbije“, Prosvjeta, 9/2002., 8-9.

\section{3.}

Karl Kaser; Hannes Grandits; Siegfried Gruber, Popis Like i Krbave 1712. godine. Obitelj, zemljišni posjed i etničnost u jugozapadnoj Hrvatskoj, SKD Prosvjeta, Zagreb 2003., 420 str. Drago RoKsandić; Čedomir VIšnNIÍ (ur.)

Drago Roksandić; Sanja LazaniN, „Bilješka: Završno izvješće ovlaštenog povjerenstva iz 1713. i popis Smiljana i Brušana“ (376); Drago RoKSANDIĆ, "Ljudi i prostori Like i Krbave 1712. godine: 'Conscriptio terrenorum et hominum beeder Graffschafften Lica vnd Corbavia' (1712.)" (393-419) 
"Ognjeslav Utješenović i Baltazar Bogišić: Ljudi i pisma“, Ljetopis Dvije hiljade treće, 2003., 261-270.

Ognjeslav UTJĚ̌ENOvić; Baltazar BoGišĺć (271-304)

Nenad Labus (prijepis); Drago RoKsandić (redaktura)

2007.

"Adam Borojević (1825.-1900.), nepoznati spisatelj” (Adam Borojević (1825 - 1900)“, Ljetopis Dvije hiljade sedme, 2007., 185-220.

Adam BOROJEVIĆ, „SPomenica mečenčanske parohije (/1842/1877. - 1894.)“ (188-220)

Drago RoksAnDIĆ (transkripcija)

\section{8.}

"Narodne 'želje' i/ili 'zahtijevanja' u proljeće 1848. godine: od podanika k građanima“, u: Hrvatski državni sabor 1848. Sv. 3, Hrvatski državni arhiv, Zagreb 2008., 21-38.

2010.

"Pisma Dragutinu Boraniću. Rade Bosnić - Dragutinu Boraniću“, Ljetopis Dvije hiljade desete, 15/2010., 178-190.

/Isprava o identitetu Baltazara Bogišića, „Kancelarija c.k. Kotarskog suda u Cavtatu, Cavtat, 18. studenoga 1899.", Zbirka Baltazara Bogišića, Hrvatska akademija znanosti i umjetnosti, Cavtat/, u: Bogišić i kultura sjećanja. Zbornik radova znanstvenog skupa s međunarodnim sudjelovanjem u prigodi stote godišnjice smrti Balda Bogišića (ur. Josip Kregar; Vlaho Bogišić; Dalibor Čepulo; Petar Miladin; Slaven Ravlić́; Filip Hameršak), Pravni fakultet Sveučilišta u Zagrebu - Leksikografski zavod Miroslav Krleža, Zagreb 2010. - 2011., prednja i zadnja klapna.

"Jean-Baptiste Feuvrier (1842-1926): cetinjski korespondent Baltazara Bogišića“, u: Bogišić i kultura sjećanja. Zbornik radova znanstvenog skupa s međunarodnim sudjelovanjem u prigodi stote godišnjice smrti Balda Bogišića (ur. Josip Kregar; Vlaho Bogišić; Dalibor Čepulo; Petar Miladin; Slaven Ravlić; Filip Hameršak), Pravni fakultet Sveučilišta u Zagrebu - Leksikografski zavod Miroslav Krleža, Zagreb 2010. - 2011., 254-299.

\section{1.}

Đuro Zatezalo, Mihajlo barun Mikašinović od Zmijskog polja, Eparhija gornjokarlovačka - Euroknjiga, Karlovac - Zagreb 2011.

Prilog I. „Baronats Diploma (Barunska diploma)“ (111-136); „Kolacioniranje prijepisa s izvornikom i stručna redaktura: prof. dr. Drago Roksandić i dr. Sanja Lazanin.“ (116); „,Sažetak barunske diplome" (137-140); „Sažetak sastavili: prof. dr. Drago Roksandić i Danijela Marjanić“" (140)

Branko Vujasinović; Čedomir Višnjić, Glina 13. maja 1941. U povodu 70. godišnjice ustaškog zločina / Đuro Roksandić, Spisak žrtava fašističkog terora godine 1941. kotara Glina, SKD Prosvjeta, Zagreb 2011.

Drago RoksAnDIĆ, „Biografija Đure Roksandića“ (155-156) 


\section{5.}

„Boško Desnica - Vladanu Desnici. Izbor pisama iz Osobne ostavštine (1933. - 1938.) Vladana Desnice“, Ljetopis Dvije hiljade petnaeste godine, 2015., 370-401.

„Svjedok o vremenu nastanka gimnazije“, u: Srpska pravoslavna opća gimnazija Kantakuzina Katarina Branković. Monografija u povodu 10. obljetnice (gl. ur. Slobodan Lalić), SPOG Kantakuzina Katarina Branković, Zagreb 2015., 27-30.

\section{6.}

Fazileta Hafizović, Popis sela i zemlje sandžaka Krka, Klis i Hercegovina oslobođenih od Mletačke Republike 1701. godine. BOA TTD 861 (Prijevod katastarskog deftera), SKD Prosvjeta - Centar za komparativnohistorijske i interkulturne studije Filozofskog fakulteta Sveučilišta u Zagrebu - Orijentalni institut, Zagreb - Sarajevo 2016., 534 str. Drago Roksandić; Čedomir Višsılć (ur.)

Drago RoKsanDić, „Defter 1701/1702., svjedočanstvo o ljudskoj i materijalnoj cijeni rata na tromedi" (493-496)

\section{Artefakti: Izvori za historiju Srba u Hrvatskoj}

\section{4.}

„Knjiga vjenčanih parohije Sv. oca Nikolaja u Rijeci, 1782-1860.“, Artefakti, 1/1994., br. 1,64 str.

Drago Roksandić (član Uredništva)

Drago RoKSANDIĆ (recenzent)

Drago RoKSANDIĆ, „Čemu Artefakti?“ (7-9); „Sažetak / Summary / Riassunto / Zusammenfassung“ $(57-64)$

\section{6.}

„Knjiga krštenih parohije Sv. oca Nikolaja u Rijeci, 1781-1869.", Artefakti, 3/1996., br. 2, 106 str.

Drago Roksandić (član Uredništva)

Drago RoKSANDIĆ (recenzent)

Drago RoKsANDIĆ, „Djeca i roditelji. Povodom objavljivanja knjige krštenih parohije Sv. oca Nikolaja u Rijeci, 1781 - 1860.“ (7-11); "Sažetak / Summary / Riassunto / Zusammenfassung“ (101-104)

\section{0.}

„Knjiga umrlih parohije Sv. oca Nikolaja u Rijeci, 1782. - 1860.", Artefakti, 4-5/2000., br. 3, 122 str.

Drago Roksandić (član Uredništva)

Drago RoKsANDIĆ (recenzent)

Drago RoKsandić, „Povodom štampanja knjige umrlih parohije Sv. oca Nikolaja u Rijeci, 1782. 1860.“ (7-10); "Sažetak / Summary / Riassunto / Zusammenfassung“ (114-121) 


\section{1.}

"Gradnja hrama Sv. oca Nikolaja u Rijeci 1776. - 1794. Zbirka građe", Artefakti, 4-5/2001., 220 str.

Drago RoksAndić (član Uredništva)

Drago Roksandić (recenzent)

Drago Roksandić, „O gradnji crkve Sv. Nikole u Rijeci i povijesti moderne Rijeke“ (7-8); „Sažetak / Summary " (216-217)

\section{4.}

"Gradnja hrama Sv. oca Nikolaja u Rijeci 1717.-1746. Zbirka građe“, Artefakti, 6-7/2004., 192 str.

Drago RoksAndić (član Uredništva)

Drago RoksAnDIĆ, „Recenzija Artefakti 6-7“ (187-188)

\section{8.}

„Inventar hrama Sv. Nikole u Rijeci“, Artefakti, 6-7/2008., 170 str.

Drago RoksAndić (član Uredništva)

Drago RokSANDIĆ, „Riječka pravoslavna crkva i njezini darodavci“ (7-8)

\section{9.}

„Knjiga vjenčanih parohije Sv. oca Nikolaja u Rijeci, 1865.-1907.", Artefakti, 10/2009., 128 str.

Drago RoksAndić (član Uredništva)

Drago Roksandić, „Recenzija“ (125-126)

\section{0.}

„Knjiga vjenčanih parohije Sv. oca Nikolaja u Rijeci, 1865.-1907.", Artefakti, 11/2010. 102 str.

Drago RoksAndić (član Uredništva)

Drago RoKSANDIĆ (recenzent)

Drago RoksAnDić, „Riječki putevi vjerske trpeljivosti“ (7-11)

\section{2.}

„Matice krštenih parohije Svetog oca Nikolaja u Rijeci, 1862.-1907." Artefakti, 1213/2012., 176 str.

Drago RoksAndić (član Uredništva)

Drago RoKSANDić (recenzent)

Drago Roksandić, „Riječ na kraju“ (173-175)

\section{6.}

„Matice umrlih parohije Sv. oca Nikolaja u Rijeci, 1880. - 1907." , Artefakti, 14-15/2016. 188 str.

Drago RoKSANDIć (član Uredništva)

Drago ROKSANDIĆ (recenzent)

Drago RokSAndić, „Predgovor“ (7-8); „Recenzija“ (185-186) 


\section{Atti del Centro di Ricerche Storiche di Rovigno}

\section{9.}

"Lujo Matutinović, soldato e scrittore", Atti del Centro di Ricerche Storiche di Rovigno, 39/2009., 269-328.

„No. 12. Memoires Historiques Politiques et Militaires sur la Dalmatie, L'strie et l'Albanie, eu égard aux Possesseurs actuels. Par Monsieur Matutinovich, Major au service de Sa Majesté l'Empereur des Francais \& Rois d'Italie. (...) Venise 18. may 1806.“ (296-325)

2010.

„Lujo Matutinović, soldato e scrittore (parte II)“, Atti del Centro di Ricerche Storiche di Rovigno, 40/2010., 765-804.

„No. 12. Memoires Historiques Politiques et Militaires sur la Dalmatie, L'strie et l'Albanie, eu égard aux Possesseurs actuels. Par Monsieur Matutinovich, Major au service de Sa Majesté l'Empereur des Francais \& Rois d'Italie. (...) Venise 18. may 1806.“ (768-802)

\section{Izložbe i katalozi - urednik, recenzent, suradnik}

\section{9.}

Hrvatske zemlje i Francuska revolucija / Les pays croates et la révolution française /katalog izložbe/, Povijesni muzej Hrvatske, Zagreb 1989., 166 str.

Drago RoksANDIĆ, „Hrvatske zemlje, francuska revolucija i napoleonski ratovi / Les pays croates, la révolution française et les guerres de Napoléon“ (13-30)

\section{5.}

Rat u predsoblju Europe. Katalog izložbe stranih knjiga, Europski pokret Hrvatska - Nacionalna i sveučilišna biblioteka, Zagreb 1995., 40 str. Suradnik na projektu.

\section{9.}

Kartografski izvori za povijest Triplex Confiniuma. Cartographic Sources for the History of the Triplex Confinium. Kartographische Quellen zur Geschihcte des Triplex Confinium, Hrvatski državni arhiv - Filozofski fakultet Sveučilišta u Zagrebu, Zavod za hrvatsku povijest, Zagreb 1999., 13, 49, 87-88. Suradnik na katalogu.

\section{3.}

"Kula Jankovića. Inicijativa obnove i oživljavanja Kule Stojana Jankovića i sela Islam Grčki“, Prosvjeta, 10 (35)/2003., br. 55 (665), 29-31.

Izložba "Njemačka - Francuska: pomirba za Europu“, 17. svibnja 2003., Zagreb - Osijek - Vukovar - Knin - Zadar - Split, Veleposlanstvo SR Njemačke - Veleposlanstvo Francuske. Član Znanstvenog organizacijskog odbora. 
2007.

Izložba „Dalmatinska zagora nepoznata zemlja“, 4. rujna - 21. listopada 2007., Galerija Klovićevi dvori. Koautor sekcije izložbe.

2013.

„Vladan Desnica i ‘Desničini susreti'“, Gradska knjižnica Zadar, 18. - 23. rujna 2013.

Drago RoksANDIĆ; Ivana CVIJOVIĆ JAVORINA (koautori)

2014.

„Vladan Desnica i 'Desničini susreti'“, Sveučilišna knjižnica u Splitu, 20. rujna - 6. listopada 2014.

Drago RokSANDIĆ; Ivana CVIJOVIĆ JAVORINA (koautori)

\section{5.}

„Vladan Desnica i 'Desničini susreti'”, Gradska knjižnica „Juraj Šižgorić“, Šibenik, 28. veljače - 11. ožujka 2015.

Drago Roksandić; Ivana CVIJOVIĆ JAVORINA (koautori)

„Vladan Desnica i ‘Desničini susreti'“, Knjižnica Filozofskog fakulteta Sveučilišta u Zagrebu, 14. - 28. rujna 2015.

Drago RoKSANDIĆ; Ivana CVIJOVIĆ JAVORINA (koautori)

\section{F. LEKSIKOGRAFSKE NATUKNICE}

Krležijana, Vol. 1-3, Leksikografski zavod Miroslav Krleža, Zagreb 1993. - 1999. Član Uređivačkog odbora.

\section{3.}

Krležijana, Vol. 1 / A-LJ, Leksikografski zavod Miroslav Krleža, Zagreb 1993., 584 str. Enciklopedijski članci:

"Borojević, Svetozar"

„Bregalnička bitka“

"Cvijić, Jovan"

"Historija“

"Jugoslavensko pitanje u prvom svjetskom ratu 1914-1918."

"Karadžić, Vuk Stefanović"

„Khuen-Hedervary, Karoly"

"Klaić, Vjekoslav"

"Kvaternik, Eugen"

1999.

Krležijana, Vol. 2 / M-Ž, Leksikografski zavod Miroslav Krleža, Zagreb 1999., 591 str.

Enciklopedijski članci:

"Marković, Svetozar"

"Mitrinović, Dimitrije" 
"Napoleon I"

"Narodnjaci"

"Novaković, Stojan"

"Obrenovići"

"Orbini, Mavro"

"O stopedesetoj godišnjici ustanka"

"Petrović Njegoš, Petar II"

„Piccolomini, Alessando"

„Pribićević, Milan"

"Pribićević, Svetozar"

"Radikali"

"Rakovac, Dragutin“

„Stjepan Radić u Beogradu“

"Stojadinović, Milan"

"Šišić, Ferdo"

"Tucović, Dimitrije"

"Za Vukovu stopedesetgodišnjicu"

„Vojna krajina"

1997.

Z. Markić; D. Roksandić, „Nevladine organizacije. Helsinki Watch“, u: Atlas Europe, Leksikografski zavod Miroslav Krleža, Zagreb 1997., 222.

\section{8.}

Leksikon Marin Držić (ur. Milovan Tatarin; Slobodan Prosperov Novak; Mirjana Mataija;

Leo Rafolt), Leksikografski zavod Miroslav Krleža, Zagreb 2008., 940 str.

Natuknice:

"Akademije"

"Archivio dello Stato u Firenci“

"Aretino, Pietro"

"Augsburg"

"Austrija"

„Budmani, Pero"

"Carigrad"

„Castiglione, Baldassare“

"Disidencija“

„Filip II."

"Habsburgovci"

"Hij (otok)"

"Jireček, Konstantin"

"Karlo V."

"Sokolović, Mehmed-paša“

"Osmansko Carstvo"

"Sveučilište u talijanskoj renesansi“

"Vojnik (plaćenik)"

"Vojvoda“"

„Zapolja, Ivan“

„Znanost, renesansna“ 
2016.

„Triplex Confinium“, u: Das Lexikon zur Geschichte Südosteuropas, 2. erweiterte Auflage (ur. Conrad Clewing; Holm Sundhaussen), Böhlau Verlag, Wien 2016.

\section{G. NEKROLOZI}

\section{7.}

„In memoriam: Péter Hanák (1921.-1997.)“, Radovi Zavoda za hrvatsku povijest Filozofskog fakulteta Sveučilišta u Zagrebu, 30/1997., 355-356.

„In memoriam: Fedor Moačanin (Zagreb, 22. kolovoza 1918. - Zagreb, 9. travnja 1997.)“, Prosvjeta. Novine za kulturu, 4/1997., br. 25, 32-34.

\section{2.}

„O Mirjani Gross post mortem“, Ekonomska i ekohistorija. Časopis za gospodarsku povijest i povijest okoliša / Economic- and Ecohistory. Journal for Economic History and Environmental History, 8/2012., br. 8, 154-159

„Mirjana Gross (1922-2012)“, Historijski zbornik, XLV/2012., br. 1, 285-287.

2013.

„Riječ na komemoraciji profesoru Renéu Lovrenčiću“, Radovi Zavoda za hrvatsku povijest Filozofskog fakulteta Sveučilišta u Zagrebu, 45/2013., 223-226.

2016.

„Ulomci iz sjećanja na profesora Renea Lovrenčića“, u: Spomenica Renea Lovrenčića (ur. Damir Agičič; Drago Roksandić; Tvrtko Jakovina), Filozofski fakultet Sveučilišta u Zagrebu, FF press, Zagreb 2016., 51-62.

2018.

„Sjećanje na prof. dr. Đorđa Stankovića (Sloboština, 21. 1. 1944. - Beograd, 9. 8. 2018.)", Prosvjeta. Novine za kulturu, 142/2018., 56-57.

\section{H. PRIJEVODI}

\section{0.}

Pierre VILAR, Zlato i novac u povijesti 1450-1920, Biblioteka Sazvežđa 99, Nolit, Beograd 1990., 451 str. Preveli s francuskog Ivo Goldstein i Drago Roksandić.

\section{5.}

Péter Hanák (ur.), Povijest Mađarske, Barbat, Zagreb 1995., 308 str. Preveli s engleskog Drago Roksandić i Veljka Čolić-Peisker. 